Ankara Üniversitesi Türk Inkılâp Tarihi Enstitüsü Atatürk Yolu Dergisi S 33-34, Mayıs-Kasım 2004, s. 167-215

\title{
Ege Sorunları Paneli
}

Ankara Üniversitesi Stratejik Araştırmalar Merkezi Müdürlüğü tarafından "Ege Sorunları" başlı̆̆ı altında düzenlenen Panel Ankara Üniversitesi Rektörlüğü 100. Y1l Konferans Salonu 30 Mayıs 2005

$14: 00-17: 30$

PROF. DR. YAVUZ ERCAN (OTURUM BAŞKANI): Sayın Rektör Yardımcılarım Prof. Dr. Ramazan Arslan, ve Prof. Dr. Ömer Gebizlioğlu ve sayın konuklar, hepinize hoş geldiniz diyor, saygılarımı sunuyorum.

Maddi ve manevi anlamda laik ve demokratik Türkiye Cumhuriyeti'nin ve cumhuriyetin ilk üniversitesi olan Ankara Üniversitesi'nin kurucusu Atatürk'e kendim ve konuşmacı arkadaşlarım adına minnet ve şükran duygularımızı sunarak paneli açıyorum.

Konuşmacılar Ege sorunlarının çok yakın geçmişi ve bugünü üzerinde duracaklar. Onların, onlara Türkiye'nin geleceği ile ilgili bu çok önemli konuşmalarında şimdiden başarılar diliyorum. Çok geniş olan panelin konusu Türk-Yunan ilişkilerinin bir bölümünü oluşturmaktadır. Ben konuşmacılara bir zemin hazırlamak amacıyla ve elimde geldiğince kısa bir şekilde Yunanistan devletinin kuruluşu ve Türk-Yunan ilişkilerinin bir tarihçesini anlatmaya çalışacağım.

Yeniçağın başlarına gelinceye kadar Avrupa'da bir Yunan sorunu yoktu. Hümanizma ve Rönesans hareketleriyle birlikte Avrupalı aydınlar Grek kültürü ile temasa geldiler ve onu kendi kültürlerinin kökeni olarak gördüler. Bu ilişkinin sonunda düşünce alanında bir Yunan hayranlığı başladı. 18. yüzyılda sömürgecilik hareketinin hız kazanması üzerine bu hayranlık özel bir değer de kazandı. Fransız aydınlarından Voltaire ve Andre Chenier, İngilizlerden Byron ve daha bir çok Avrupalı yazar ve düşünürler Yunan edebiyatının hayranıydı. Dolayısıyla sürekli olarak Yunanlılar lehinde ve Türkler aleyhinde yazılar yazdılar. Aydın halk bu yazıların etkisiyle sadece Yunanlıların değil, Osmanlı İmparatorluğu'nun her yanına dağılmış olan Rumların da geleceği ile ilgilenmeye başladı. Çünkü Rumlar ile Yunanlılar arasında onlara göre sadece kültürel değil, etnik köken birliği de bulunuyordu. 
Yunan olaylarının başlamasının elbette başka nedenleri de var. Yunanlıların ve Rumların bu çalışmaları sonunda 1814 yılında ikisi Rum, biri Bulgar olmak üzere üç tüccar tarafından ve Yunan bağımsızlığını hedef kabul eden Etnik-i Eterya Cemiyeti kuruldu.

İlginçtir; Eflak Voyvodası, İstanbul Rum Patriği Gregoryos ve Divani Hümayun tercümanı Nikola Morazi Eterya'nın etkili üyeleri arasındaydı. Bu olayların olduğu yıllarda Tepedelenli Ali Paşa İyanya ve Mora bölgesinde görevliydi, Yunanlıların ve Rumların bu çalışmalarını yakından izliyordu. Durumu İstanbul'a bildirerek önlem alınmasını istedi. Fakat II. Mahmut'un mühürdarı Halet Efendi, Tepedelenli kendisine hediye göndermeyi kestiği için kızgındı. Bu nedenle padişahı ikna ederek divan tercümanı Nikola Morazi'yi incelemeler yapmak üzere Mora'ya gönderdi. Elbette Morazi'nin raporunu tahmin etmek zor değil. Raporda Tepedelenli'nin söylediği gibi Yunanlıların bir takım hazırlıklar yapmadığından ve Yunan reayanın Osmanlı Devleti'ne olan kesin bağlılığından söz ediliyordu.

İstanbul'daki alınganlıklar ve kişisel çıkarlarını ülke çıkarlarının önünde tutanların aptalca kararları sonunda Tepedelenli Ali Paşa asi ilan edildi ve üzerine kuvvet gönderildi. Böylece hem Yunanlıların en büyük korkusu Tepedelenli ortadan kalkmış hem de Mora ve İyanya'da olası bir olayı kontrol edecek Osmanlı kuvvetleri bölgeden uzaklaşmış oluyordu. Bu durumu göz önüne alan Yunanlılar ayaklanma için uygun zamanın geldiğine karar verdiler ve 13 Şubat 1821 tarihinde Mora'da ayaklanma başladı. Osman Devleti ayaklanmayı bastırmak için büyük çabalar harcadıysa da başarılı olamadı. 1824 yılında Mısır Valisi Mehmet Ali Paşa ayaklanmayı bastırmakla görevlendirildi. Oğlunun komutasında gönderilen kuvvetler ayaklanmayı bastırdı. Ancak tam Yunan ayaklanmasının bittiği düşünülürken bugün de olduğu gibi Avrupa devletleri işe karıştı.

İngiltere ve Rusya Yunanistan'a bağımsızlık verecek olan St. Petersburg Protokolünü Nisan 1827'de imzaladılar. Üç ay sonra da bu kez Fransa, Rusya ve İngiltere aynı konu ile ilgili olarak Londra Anlaşması'nı imzaladı. 1827 yılı sonunda protokol ve anlaşmayı Osmanlı Devleti'ne kabul ettirebilmek için müttefik donanması Navarin'de bulunan Mısır ve Osmanlı Donanması'nı yaktı. Ertesi yıl, yani 1828 'de Rusya, Osmanlı Devleti'ne savaş ilan etti. Hemen hemen bütün Balkanlar Rus işgali altına girdiği gibi, Edirne de işgal edildi. Doğuda ise Kars, Ahıska, Anapa ve Erzurum Rusların eline geçti.

Sonunda Osmanlı Devleti barış istemek zorunda kaldı ve 14 Eylül 1829 tarihinde Edirne Anlaşması imzalandı. Bu anlaşmanın son maddesine göre Osmanlı Devleti İngiltere ve Rusya arasında imzalanmış olan St. Petersburg Protokolünü kabul ediyordu. Böylece bağımsız bir Yunan Devleti kurulmuş ve 175 yıldan beri süregelen Türk-Yunan ilişkileri de başlamış oluyordu. 
Bağımsız bir Yunan Devleti'nin kurulması Osmanlı İmparatorluğu'nun dağılmasında bir başlangıç noktasıdır. Ayrıca çeşitli etnik gruplardan oluşan Osmanlı İmparatorluğu halkı için Yunan Krallığı bundan böyle örnek olmuştur. 175 yıllık Türk-Yunan ilişkileri genellikle olumsuz geçmiştir. Yunanistan Avrupa devletlerini arkasına aldığı her firsatta Osmanlı toprakları üzerinde yayılmacı bir politika izlemiştir. Yalnız kaldığı zamanlarda ise Osmanlı-Yunan veya Osmanlı-Türk dostluğu başlamıştır. Bu politika her iki ülke için de zararlı olmuştur, ama Yunanistan bunu hep yapmıştır. Türk devlet adamları Atatürk'ün politikasını izleyemediği sürece de yapmaya devam edecektir.

Özellikle Birinci Dünya Savaşı sırasında Ege Adaları'nı -deyim yerindeyse- armut gibi toplayan Yunanistan 1912 yılında Girit'i, İkinci Dünya Savaşı sonunda Rodos ve 12 Adaları ele geçirmişti.

Son yıllarda Kıbrıs üzerindeki çalışmaları hızlı bir ivme kazanmıştır. Henüz resmen ilan edilmemiş olmasına ve Türkiye'nin şiddetli muhalefetine rağmen, bana göre adanın Yunanistan'a ilhakı ileride söz konusu olabilir. Yunanistan'in bu yayılmacı politikası neredeyse, aslen Makedon olmasına rağmen, Büyük İskender'in ayağını bastığı her yeri Yunanistan kabul etmek gibi bir aşırılığa ulaşmıştır.

Türk-Yunan ilişkileri içinde Ege ayrı bir önem taşımaktadır. Hepsi Yunanistan tarafından yaratılmış olan Ege hava sahası, kıta sahanlığı, karasularını 12 mile çıkararak denizi tümüyle kapatmak, Türkiye'nin Ege'de petrol aramasına engel olmaya çalışmak ve çeşitli kayalıklara el koyma girişimleri sorunların belli başlılarıdır.

Ege'yi Türkiye'ye kapayan Yunanistan, Kıbrıs ile de Doğu Akdeniz'i kapatma yolundadır. Bunu başardığı zaman Türkiye üç tarafı denizle çevrili bir kara devleti olacaktır. Yaklaşık 120 yıl boyunca Avrupa devletleri ve Yunanistan'ın Osmanlı Devleti'ne karşı izledikleri politika ile aynı ülkelerin Türkiye Cumhuriyeti'nin son 50 yllında izledikleri politika neredeyse birebir örtüşmektedir. İşte bu panelde Türkiye'nin geleceği açısından olağanüstü önemli bu stratejik konular konuşulacak ve tartışılacaktır.

Bu kısa girişten sonra şimdi sıra konuşmacılarda. İlk konuşmacı Ankara Üniversitesi'nin yetiştirdiği değerli bilim adamı olan ve şimdi de Atılım Üniversitesi'nde aynı değerli hizmetini sürdürmekte olan Prof. Dr. Hüseyin Pazarcı'dır.

Sayın Pazarcı'nın kısa özgeçmişi şöyle:

Paris Hukuk Fakültesi ve Paris Edebiyat Fakültesi Sosyoloji bölümü mezunudur. Paris II. Üniversitesi'nde yüksek lisans ve doktora çalışmalarını tamamlamış, 1972 yılı Ocak'ından itibaren Ankara Üniversitesi Siyasal Bilgiler Fakültesi Uluslararası Hukuk Kürsüsü'nde doktor asistan olmuş, daha sonra doçent ve 1985 'de profesörlüğe yükseltilmiştir. 
Siyasal Bilgiler Fakültesi'nde 1977'den itibaren Uluslararası Hukuk Kürsüsü Başkanı, 1988-1989 yıllarında Devlet Planlama Teşkilatı, AET Hukuk ve Eğitim Dairesi Başkanlığı ve Türkiye Cumhuriyeti Dışişleri Bakanlığı ile ilgili çeşitli uluslararası toplantılara katılması söz konusu olmuştur.

1989-1997 yılları arasında Dışişleri Bakanlığı Baş Hukuk Müşavirliği, 1997-2001 yılları arasında ise Türkiye Cumhuriyeti Tunus Büyükelçiliği görevlerini yapmıştır. 2001-2004 yılları arasında Siyasal Fakültesi Uluslararası İlişkiler Bölümü Başkanlığı yaptıktan sonra, Temmuz 2004'de emekli olmuştur.

Konuşmacılar ilk oturumda konuşma sürelerini 20 dakika olarak kullanacaklar. Buyurun Sayın Pazarcı, söz sizin ve süreniz başladı.

PROF. DR. HÜSEYIN PAZARCI: Sayın Başkan, Sayın Denizcilik Müsteşarımız, Üniversitemizin Sayın Rektör Yardımcıları, Sayın Amiralim ve değerli konuklar; "Ege sorunlarını bugün ele almanın özel bir anlamı var mı?" diye sorabilirsiniz. İlk önce ben de sordum. Çünkü görünürde, en azından gündemde olan bir konu değil. Ama bu görünürde ve gündemde olmama olayı aslında Ege sorunlarının hiçbir zaman bunların gündem dışında kaldığını da göstermiyor. Bugün Ege sorunları, her ne kadar uzun uzun kamuoyu önünde tartışlan konular şeklinde yer almıyorsa da, TürkYunan ilişkileri itibarıyla ve Türkiye'nin gelecekteki belki bugün Avrupa Birliği ile olan ilişkilerinde hep önemli bir etken olarak yer alıyor. Dolayısıyla da Ege sorunları taraflar arasında veyahut taraflar dişı, Avrupa Birliği merkezli bazı forumlarda hep ele alınan konular içinde yer alıyor. Dolayısıyla bugün çok güncel bir sorunmuş gibi görünmemesi bunların unutulduğu veya çözüldüğü anlamına gelmiyor. Ege konusundaki Türk ve Yunan tezleri aynen, ilk başında bu sorunlar ortaya çıktığı şekliyle sürüyor ve Türkiye'nin ve Yunanistan'ın tutumları da bu konuda aynen devam ediyor. Bugün Kıbrıs daha çok gündemde olmasına rağmen, önümüzdeki yıllar içinde Ege Sorunları daha çok öne çıkacak sorunlardan bir tanesidir. Unutmamamı, konuyu hep inceleyip, ne yapabileceğimiz konusunda değerlendirmeler yapılması, ülkemiz açısından önemli bir gereklilik arz etmektedir.

Şimdi "Ege sorunları" dediğimizde ilk önce sizlere bu çok karmaşık olan Ege sorunlarının ne olduğunu kısaca bildirmemde, özetlememde yarar var zannediyorum. Doğrusunu isterseniz; "Bu konuşmayı gel katıl, aramızda yap" dediklerinde çok uzun yıllar bu sorunlarla uğraşmı̧ olmama rağmen ben bile bazen hatırlama gereğini duyduğumu gördüm. Dolayısıyla sizlere de o anlamda hatırlatmakta yarar var.

Ege sorunları üç kategoride gelişen bir sorun şeklinde özetlenebilir. Bu sorunların birinci grubu, deniz yetki alanları ile ilgili; ikinci grubu hava sahası ile ilgili; üçüncü grubu da adaların hukuksal durumu ile ilgilidir. 
Deniz alanlarıyla ilgili olan konulara baktığımızda karşımıza çıkan sorunlardan bir tanesi; henüz potansiyel bir sorun olan, ama tezler ve iddialarla tam bir karşıtlı̆̆ı gösteren karasuları genişliğiyle ilgili olan sorundur. Yunanistan karasularını 12 mile çıkarabileceğini ve bu hakkın kendisine ait olduğunu dile getirirken, biz de Ege'de böyle bir yola başvurulmaması gerektiğini, Ege'de, en azından bu bölgenin özel koşulları nedeniyle, buna hakkı olmadığını ifade ediyoruz. Bir gün bu sorun patlarsa, açığa çıkarsa, çok temel bir sorunu oluşturacak.

İkincisi; bu güne kadar açığa çıkmış bir sorun, kıta sahanlı̆̆ı sınırlandırması sorunudur. Kıta sahanlığı sınırlandırması sorunu 1973-1974 yıllarında ortaya çıkmış bir sorundur. Kıta sahanlığının belki ilk önce ne olduğunu söylemek ve hatırlatmakta yarar var. Kıta sahanlı̆̆ı bir devletin, kara ülkesinin denizin altında oluşturduğu doğal uzantısıdır. Yani sadece deniz tabanı ve toprak altını kapsayan, su tabakasıyla, denizle, denizin su kısmıyla ilgisi olmayan bir kavram; taban ve onun toprak altını ifade ediyor. Bu kıta sahanlığı konusunda özellikle Türkiye'nin karşısında adaların, Yunanistan'a ait adaların bulunması nedeniyle bu sorunların çözümünde, birçok teknik hukuksal, çelişkili karşılıklı tutumlarla karşılaşıyoruz. Dolayısıyla kıta sahanlığı sorunumuz var.

Bunların dışında, tabii kara suları ilan edildiği takdirde kara sularının sınırlandırması söz konusu olacak. Bu da 12 Adalar bölgesi dışındaki bölgeler bakımından sınırlandırılmış değildir.

Daha başka sorunlar da var. Örneğin bir arkeolojik bitişik bölge sorunu var. Pek konuşulmaz ve bu nedenle de ortaya özel olarak çıkmış bir sorun değildir. Ama denizin tabanındaki arkeolojik ve tarihsel verilerin, batıkların hangi devlet tarafından denetlenebileceği ve hangi devletin o bölgede yasalarının geçerli olacağı konusunda bir arkeolojik bitişik bölge veya kültürel bölge ilan edilmesi üzerine yıllardır UNESCO çerçevesinde de çalışılan konulardır. Oysa tabanı ilgilendirdiği için arkeolojik ve tarihsel yapılar, bu kıta sahanlığı sınırlandırmasını da doğrudan etkileyebilecek bir sonuç doğuracak niteliktedir. Dikkatimizi şu an için çekmiyor, ama ileride bu arkeolojik bitişik bölge sorununun da çıkabileceğini ve bunun hafife alınmaması gerektiğini, doğrudan kıta sahanlığı sınırlandırmasını ve hatta karasuları genişliğini ve sınırlandırmasını etkileyebileceğine şu an için dikkatinizi çekmekte yarar gördüm.

İkinci grup sorunlar hava sahası ile ilgili dedik. Hava sahası ile ilgili bir 10 millik hava sahası ilanı var Yunanistan'ın. Halbuki kara suları genişliği bugün biliyorsunuz 6 mildir. Ege'de “İt dalaşı” denilen, savaş uçaklarının sürekli birbirlerini tacizi olayı yaşanıyor. Bu, 6 millik karasularına karşılık, Yunanistan'ın 10 millik bir hava sahasına sahip olmasından kaynaklanan bir sorundur. 
Bir başka hava sahası sorunu, FIR sorunu oluyor. Bu "uçuş bilgi bölgesi" denilen bölgeye ilişkin yetkilerin Yunanistan tarafından kullanılmasıyla ilgili bir sorundur.

Size olabildiğince bütün bu konuları aspirin şeklindeki özetini vermeye çalışıyorum.

Üçüncüsü adaların hukuksal durumu dedik. Adaların hukuksal durumu ile ilgili olarak 1995 yılı sonu ve 1996 başlarında kesin olarak bir uyuşmazlık ortaya çıkmıştır. Burada tarafların iddialarının ve tezlerinin daha önceden birbirleriyle karşıt olduğu adacık ve kayalıkların aidiyeti sorunu vardir.

İkincisi ise yine adaların hukuki durumu ile ilgili, ama aidiyet sorunu değil de, egemenliğin sınırları sorunudur. Yunanistan'a bırakılan doğu Ege adalarının silahtan ve askerden arındırılmış statüsü sorunu bulunmaktadır. O konuda da anlaşamıyoruz.

$\mathrm{Bu}$ konularla ilgili olarak üç kişiyiz burada, üç konuşmacı olarak bize görev verildi. Karasuları ve hava sahası ile ilgili sorunları benden sonra arkadaşım Prof. Sertaç Başeren nakledecek ve değerlendirmesini yapacaktır. Adacık ve kayalıkların statülerine ilişkin verilerle ilgili olarak ise Denizcilik Müsteşarlığı Genel Müdürü Ali Kurumahmut sizi bilgilendirecek ve bu konuları değerlendirecekler, tartışacaklar.

Ben bu saydığım başlıca sorunlardan sadece ikisine ilişkin birazcık daha ayrıntılı bilgileri verip konuşmama son vereceğim, sözü arkadaşlarımıza aktaracağım.

Ege sorunlarına baktığımız zaman sorunların belki de kronolojik olarak ilkini oluşturan, sorunların kaynağı 1930'lu yıllara kadar gidiyor. Türkiye ile Yunanistan arasında tam bir uyuşmazlık haline dönüşme konusu itibarıyla 1960'lı yıllara varan, ilklerden olan doğu Ege adalarının silahsızlandırılması ve askerden arındırılması konusunu ilk önce size takdim edeceğim. Ondan sonra da, kıta sahanlığı sınırlandırmasına ilişkin olarak, 1973-1974 yılı sonlarında çıkan kıta sahanlığı konusu ile ilgili size öz bilgileri vermeye çalışacağım. Gerçekten bütün bu sorunlar, son derece teknik ve hukukçuların da her zaman çok berrak göremediği veyahut da anlaşamadığı sorunlardır.

Şimdi doğu Ege adaları ile ilgili olarak ve bunların askerden ve silahtan arındırılması konusuyla ilgili olarak ilk önce bu doğu Ege adalarının nasıl silahsızlandırıldığı ve askerden arındırıldığını size sunmak istiyorum. Doğu Ege adalarının silahsızlandırılmasıyla ilgili veriler ilk kez 1923 Lozan Barış Andlaşmasıyla ortaya çıkmıştır. Biliyorsunuz Lozan Andlaşması ile "12 Adalar" dediğimiz adalar, Ege'nin güneyinde kalan, doğu Ege'nin güneyinde kalanlar İtalya'ya bırakılmıştır. Kuzeyde kalanlar, Sakız, Sisam ve Midilli gibi adalar da Yunanistan'a bırakılmıştır. Daha önce Sayın Hocamız size işin tarihçesini verirken o adaların evveliyatından söz etti. 
Ama sonuç itibarıyla bugünü belirleyen veriler Lozan Andlaşması ile başlıyor.

Lozan Barış Andlaşması'nın 12. maddesi doğu Ege adalarının ilke olarak silahtan, askerden arındırılmasını öngörmüştür. Bu ilkeyi koyduktan sonra 13. maddesi Sakız, Sisam, Midilli gibi büyük adalar ve o civardaki diğer başka adalarla ilgili olarak, "merkezi doğu Ege adaları" dediğimiz adaların silahsızlanmasına ilişkin özel düzenlemelere girmiştir. Bunlar ne gibi düzenlemeler? "Sadece güvenlik güçleri bulunduracak, bunlar hafif silahlar taşıyacaklar, sayısı şu kadarı geçemeyecek" türünden verilerdir. İlke silahsızlanma, ama tabii kamu düzeni vesaire bakımından da bir küçük silahlanma, hafif silahlarla silahlanma gibi kısitlı sayıda silahlanmaya ve asker bulundurmaya da olanak veren bir sistem öngörülüyor. Bu durum 1947 Paris Barış Andlaşması ile 12 Adalar ve Meis bakımından da aşağı yukarı aynı nitelikleri ile tekrarlanmıştır. Böylece Lozan Andlaşması ile 12 Adalar İkinci Dünya Savaşı'ndan sonra el değiştirmesinden kaynaklanıyor sorunİtalya'ya bırakılmış iken bundan böyle 1947 Paris Barış Andlaşması ile Yunanistan'a geçiyor. Ama o zaman onların da askerden ve silahtan arındırılması gerektiği kabul ediliyor. Paris Barış Andaşması'na Türkiye taraf değil. Biz o konferansa katılmamış bulunuyoruz. Ama Türkiye'nin güvenlik nedenleri göz önünde tutularak silahsızlanmaya bu adalar bakımından da gidilmiştir.

Bu konudaki silahsızlanma hükümlerinin delinmesi, Yunanistan tarafından askerleştirmeye ve silahlanmaya başlanması, özellikle ilk dönemlerde bir- iki havaalanı, askeri kullanımlı havaalanı yapımı şeklinde ortaya çıkıyor. Sonuçta 1960'lı yıllarda, 1960'lı yılların sonunda olay artık gerçek bir uyuşmazlık haline dönüşüyor. Çünkü örneğin 1969'da -en azından bu benim görebildiğim bir belge, bulabildiğim bir belge, daha evveliyatı da muhtemelen vardır diye düşünüyorum- 1960'lı yılların sonunda Türkiye Yunanistan'ı "Doğu Ege adalarını silahlandırıyorsun, askerleştiriyorsun" diye protesto ediyor. Yunanistan ise "Benim hakkımdır, ben bunları yaparım" şeklinde cevap vermiyor. Önceleri "Ben böyle bir şey yapmıyorum" veya "Bu askeri amaçlı değil" veyahut "NATO çerçevesindeki bazı şeylerdir" türünden cevaplarla bunu geçiştirmeye çalışıyor. Ama 1970'li yıllara gelindiğinde, özellikle kıta sahanlığı sorunu ve sonra 1974'deki harekâttan sonra Kıbrıs Sorunu da ortaya çıkınca, Türk-Yunan sorunları çok geniş bir yelpazede yer almaya başlıyor. İşte o zaman Yunanistan bu doğu Ege adalarının askerleştirilmesi ve silahlandırılması konusu ile ilgili olarak da, "Bu benim hakkımdır" diyor, artık inkâr yolunu terk ediyor ve tezlerini ortaya sürmeye başlıyor.

Konuyu özetleyecek olursak, değişik forumlarda, yazışmalarda Yunan tezinin özü doğu Ege adalarının askerleştirme ve silahlandırma hakkı bulunduğu konusunda şu gerekçeler üzerine oturuyor: 
Birisi; uluslararası hukukta özellikle "Rebus Sic Stantibus" diye bir ilke vardır: "Koşulların köklü değişmesi" anlamı taşır. Bu "koşullar köklü değiştiği takdirde bir andlaşma da sona erebilir" şeklindeki bir ilkedir. İşte koşullar köklü değişikliğe uğradığı İkinci Dünya Savaşı'ndan sonra, -ondan önce de Montrö Sözleşmesi ile Boğazlar Sözleşmesi vardı- Yunanistan koşulların köklü olarak değiştiğini ileri sürerek; yeni güvenlik gereksinmeleriyle adaları askerleştirmek ve silahlandırmak istemektedir. Yunanistan hukuken bunun olanaklı olduğunu iddia etmektedir. Oysa koșulların değişmesi olayının hukuksal değerlendirmesi yapıldığında, o andlaşmanın yapılmasını etkileyen çok temel koşulların değişmiş olması aranır. Yunanistan'ın bu adaları bakımından böyle bir temel gerekçe görünmüyor. Uzun uzun tartışamıyorum, ama işin özü bu. İkincisi de koşulların köklü değişmesi durumunda otomatik olarak hemen bir ikili andlaşmayı iptal etme, feshetme veya çok taraflı antdaşmadan çekilme, onu yok sayma söz konusu olmamaktadır. Rebus Sic Stantibus ilkesi bizim de bir devirde başvurduğumuz ilkelerden biri oldu. Örneğin 1923 Lozan Boğazlar Sözleşmesi'nin Montrö Boğazlar Sözleşmesi ile değiştirilmesini istediğimizde ve 1936 'da bunu nasıl elde ettik diye baktığımızda bu durum görülür. Ancak biz diğer taraflarla yine tartışarak, görüşerek Lozan Boğazlar Sözleşmesi yerine Montrö Boğazlar Sözleşmesi'ni koyduk. Dolayısıyla uluslararası hukukta "Koşullar köklü değişti" diyerek, "Ben bütün yükümlülüğünden kurtuldum” demek gibi bir hak yoktur.

İkincisi Yunanistan'ın bu adaları silahlandırabileceği konusu özellikle Boğazönü Adaları dediğimiz Limni vesaire gibi adaları da ilgilendiriyor. Burada Boğazönü adaları ile ilgili olarak Yunanistan şöyle demektedir: “Montrö ile Türkiye'nin daha önce Lozan Boğazlar Sözleşmesi ile askerden ve silahtan arındırılmış olan boğazlar bölgesi ve Boğazönü, Türkiye'ye ait Boğazönü adaları, Gökçeada, Bozcaada silahlandırma hakkını kazanmıştır. (Gerçekten Montrö Sözleşmesi'nin eki olan protokolle bu hak açıkça Türkiye'ye tanınmıștır). Yunanistan, dolayısıyla aynı gerekçe bizim için de geçerlidir, Montrö Boğazlar Sözleşmesi ve ekleri Yunanistan bakımından da artık Boğazönü adalarının en azından Yunanistan'a askerleştirebilme olană̆ını tanımıştır demektedir." Bu çerçevede bir de belki o dönemin Dışişleri Bakanı olan Tevfik Rüştü Aras'ın çok özenle kurulmamış bazı temenni cümlelerinden Yunanistan birtakım sonuçlar çıkarmaya çalışmıștır. Aras Montrö Boğazlar Sözleşmesi'nin Meclis'e sunulması sırasında; "Boğazlar ve Boğazönü adaları bu sözleşmeyle askerileşiyor, aynı şeyi tabii komşumuz Yunanistan için de temenni ediyoruz" türünden bir takım söylemlerde bulunuyor. İşte burada Yunanistan "aynı şey bizim için de geçerlidir" türünden iddialarda bulunuyor. Ama bunlar da, incelendiği zaman, en azından biz Türk hukukçuları, bunların temenni niteliğinde kalan sözler olduğunu, kesin bir hukuksal sonuca bağlamaya yeterli olmayacağını ifade ediyoruz. 
Yunanistan'ın doğu Ege adalarını askerleştirirken ileri sürdüğü bir başka gerekçe, daha sonraki yıllarda, 1974'ten sonraki yıllardaki gerekçesi olmuştur; "Meşru savunma hakkımı kullanıyorum. Siz Türkiye olarak özellikle Ege Ordusu'nu kurdunuz. Ege Ordusu doğu Ege adalarına karşı kurulmuş bir ordudur. Ben buna karşı savunma hakkımı kullanıyorum ve adaları askerleştiriyorum, silahlandırıyorum" deme yoluna gitmiştir. Uluslararası hukukta meşru savunma hakkının ne olduğunu değerlendirdiğimizde, bu gerekçe de tutarlı bir gerekçe değildir. Meşru savunma hakkı bugün uluslararası hukukta genel kural olarak, bir teamül, bir yapılageliş kuralı olarak kabul edilen kurallardan biridir. Ayrıca da Birleşmiş Milletler Andlaşması'nın 51. maddesinde ifadesini bulan bu kural şunu öngörmektedir: Bir devlet fiilen bir saldırıya uğradı̆̆ı takdirde ona hiçbir başka yerden izin almaya gerek olmadan kuvvet kullanmak suretiyle cevap verir. Meşru savunma, dolayısıyla bir kuvvet kullanmaya maruz kalan bir devletin ona yine kuvvetle bu kez cevap vermesi konusundadır. Ama koşulu saldırıdır, fiili saldırıya uğramaktır. Bugün uluslararası hukukta; "Çok yakın (imminent) bir saldırı durumunda da kullanılabilir" deniliyor. Ama o çok yakın bir saldırıya uğrama durumunda meşru savunma hakkının kullanılması olayında şöyle örneklere rastllyoruz:

Örneğin Mısır-İsrail Savaşı sırasında Mısır Ordusu'nun uçakları yarım saat, bir saat gibi çok kısa bir süre içinde topraklarına saldıracağı şeklinde bir değerlendirme yapan İsrail, kalkışa hazırlanan uçakları havaalanında gelip vurmuştur. İsrail; "Bu meşru savunma hakkı!" iddiasında bulunmuş "Ama fiilen sana saldırılmadı" dendiğinde ise "Ama saldırılmak üzereydi, yarım saat sonra belki aynı konumda ben kalacaktım, onun için bu hakkımı kullandım" demiştir. Ama bu tartışılıyor. Fiili saldırı durumu dışındaki her türlü meşru savunma hakkı gerekçesi tartışlıyor. O kadar kolay hemen kabul edilmiş değil. Her haliyle Yunanistan'ın doğu Ege adalarını bu çerçeveye sokabilmesi olanağı yok. Doğuda, Ege'de bir ordu, Dördüncü Ordu kuruldu diye hemen bir yakın saldırı olasılığı ve dolayısıyla buna bağlı bir meşru savunma olasılığı hukuken yoktur. Bu da dolayısıyla tutarsız olan bir hukuksal iddia oluşturuyor.

Son yıllarda Yunan devletinden ziyade bazı Yunanlı yazarların ileri sürdüğü bir dördüncü gerekçe var: Bu "1947 Paris Barış Andlaşması'na Türkiye taraf değildir, bu taraflar arasında konuşulur, görüşülür, değerlendirilir -silahlandırılıp, silahlandırılamayacağı konusu- dolayısıyla sizi ilgilendirmez" niteliğinde bir tezdir. Ancak uluslararası hukukta objektif statü yaratan andlaşmalar vardır. Normalde andlaşmalar sadece tarafları bağlar, ama bazı andlaşmalar vardır ki herkesi bağlar. Bu herkesi bağlamanın en önemli örneklerinden bir tanesi de Boğazlar ile ilgilidir. Örneğin Montrö Sözleşmesi'dir. Montrö Sözleşmesi 9-10 devletin taraf olduğu bir sözleşmedir, ama dünyanın 200 civarı devletinin gemisi geçerken o kurallara uyar. Örneğin"Ben Brezilya'yım, sözleşme tarafı değilim, ben 
istediğim gibi geçerim! Siz kendi aranızda bunun kurallarını uygularsınız geçiş koşullarını!" diyemez.

$\mathrm{Bu}$ adaların askerden arındırılması olayı da böyle bir olaydır. Objektif statü yaratan bir veridir. Belki birkaç devletin gerçekleştirdiği bir andlaşma olabilir, ama ondan sonra herkesin buna saygı duyması gerekmektedir. Mesela objektif statü yaratan başka bir örnek İsviçre'nin tarafsızlığı olayıdır. Bu sürekli tarafsızlıktır. Bu düzenleme 1815 Viyana Kongresi Son Senediyle gerçekleştirilmiştir. Ama başkaları; "Ben taraf değilim diye ben seni tarafsız devlet konumunda görmüyorum" deme hak ve yetkisine sahip değildir.

Askerden arındırılma konusunda Aaland Adaları örneği de vardır. 1920'lerde Milletler Cemiyeti'nde objektif statü yarattığı için Aaland Adalarını silahtan arındıran andlaşmaların bütün devletler için ve özellikle bölge devletleri için de geçerli olduğu ileri sürülmektedir.

Şimdi dolayısıyla Yunan tezleri bunlardır. Bunların hepsi cerh edilebilecek durumdadır. Türkiye aşağı-yukarı dediğim nitelikte cevaplarla, bunları resmi yazışmalarında, tezlerinde de ifade etmiştir. Bu konuda anlaşılan Yunanistan da o kadar haklarının dayanma gücünden, temelinden kuşkulu ki, 1993 yılında Uluslararası Adalet Divanı'nın zorunlu yargı yetkisini tanırken bütün uluslararası uyuşmazlıklar, karşılılık koşuluyla; "Öbür devletler de aynısını tanırsa, benim bakımımdan Divan önüne gelebilir, Divan bu konuya bakabilir" diye yargı yetkisini tanırken bir konuyu dışında bırakmıştır: ulusal güvenlik amaçlı aldığı askeri önlemler yargı yetkisi dışındadır. Bu çekince doğu Ege adalarının askerden arındırılması konusuna yönelik bir çekincedir.

Konuşmamın adalara ilişkin kısmını burada bitirmek istiyorum. Şimdi biraz kıta sahanlığı ile ilgili bir şeyler söyleyeceğim. Kıta sahanlığının özünü söyleyeceğim, sadece sorunun özünü dile getirmek istiyorum.

Türkiye'nin karşısında adalar var. Bunların doğu Ege adaları ve 12 Adalar gibi çok yakın olanları var. Daha arkasında Ege'deki öteki adalar bulunmaktadır. Kıta sahanlığı bir devletin, kara ülkesinin doğal uzantısı olarak normalde kıyı devletine geliyor. Ancak bir başka devletin önünde adalar olduğu zaman, o adayla bir başka devletin anakarası arasında Türkiye'nin Anadolu'su ile Yunanistan'ın adaları arasında- ne gibi bir sınırlandırma yapılması gerekir? Çünkü uluslararası hukukta adaların da kıta sahanlığı vardır diye kabul ediliyor.

O zaman işte bu kıta sahanlığı sınırlandırmasında sorun adalara ne kadar etki tanınacaktır?

Sorun "Anakara ile eşit etki mi tanıyacağız, yani sınırı ortadan mı geçireceğiz, adayla Türkiye'nin Anadolu'su arasından mı, yoksa adalara sınırlı etki, hatta çok yakın olanlarına sadece karasuları bırakmak suretiyle hiçbir kıta sahanlığı etkisi tanımayacak mıyız?" sorusu üzerine oturuyor. İki 
tarafça da bu konuda çok değişik tezler ileri sürülüyor. Ama işin özü budur. Türkiye bu çerçevede Ege'nin yarısına kadar, Yunanistan'a adaların da arkasına geçebilecek, batısına geçebilecek bir şekilde Ege'nin tabanının Türkiye'nin kıta sahanlığı olduğunu söylüyor. Yunanistan ise "Bu iş bizim doğu Ege adalarıyla Anadolu arasındaki sınırdan geçer" şeklinde iddiaları var. Ama uluslararası hukuk bu işin çözümünün hakça ilkelere göre yapılması gerektiğini ifade ediyor. Hakça ilkelerin tam ne olduğu, her zaman ortaya çıkmamakla birlikte, yine de adalara az etki, kısmı etki veya hiç etki tanınmaması gibi değerlendirmeler ve mahkeme kararları vardır. Dolayısıyla biz Ege konusunda yine bizim iddia ettiğimizin doğru olduğunu ifade ediyoruz. Teşekkür ederim.

PROF. DR. YAVUZ ERCAN (OTURUM BAŞKANI): Sayın Pazarcı konuşmasının başında bir anlamda, teşekkür anlamında; "Can sıkıcı konuları dinlemeye geldiniz" dedi. İzin verirlerse ben buna bir cümle eklemek istiyorum. Bugün can sıkıcı konuları dinlemek istemeyenler, yarın can sıkıcı bir hayatı bile bulamayacaklardır.

Evet, bu oturumun ikinci konuşmacısı Ankara Üniversitesi Siyasal Bilgiler Fakültesi Uluslararası İlişkiler Bölümü Öğretim Üyesi Prof. Dr. Sayın Sertaç Başeren'dir.

Sayın Başeren'in kısa özgeçmişi şöyledir:

1955 Sivas'ta doğan Başeren, 1978 yılında Ankara İktisadi ve Ticari İlimler Akademisi'nden, 1982 yılında Ankara Üniversitesi Hukuk Fakültesi'nden mezun oldu. 1987 terörizm konusundaki çalışmalarıyla doktor oldu, 1996'da doçent ve 2003'de profesör unvanlarını aldı. Sayın Sertaç Başeren'in kuvvet kullanma ve Ege sorunları konusunda kitap ve makaleleri vardır. Buyurun Sayın Başeren, söz sizin.

PROF. DR. SERTAÇ BAŞEREN: Teşekkür ederim efendim. Ben karasuları ve hava sahası konusu üzerinde konuşacağım. Fakat karasularına ilişkin şöyle bir mesele var: Karasuları konusu egemenlik problemleriyle çok yakından bağlantılıdır. Egemenlik meseleleri halledilmeden karasuları konusunda çok gerçekçi değerlendirmeler yapabilmek mümkün değildir. Bir süredir Ege'de bir egemenlik sorunu var. Bu sorun hakkında ben izninize sığınarak önce Sayın Başkanım, Ali Kurumahmut'un bir değerlendirme yapmasını istiyorum. Çünkü ona bağlı olarak benim söyleyeceklerim daha kolay olacak. Biraz işimi kolaylaştırmak istiyorum.

PROF. DR. YAVUZ ERCAN (OTURUM BAŞKANI): O zaman izin verirseniz konuşmadan önce Sayın Kurumahmut'un özgeçmişini de okuyayım. 1960 yılında Trabzon'da doğdu. 1982'de Deniz Harp Okulu'ndan, 1988 yılında İstanbul Üniversitesi Hukuk Fakültesi'nden mezun oldu. Yüksek lisans eğitimini Marmara Üniversitesi Hukuk Fakültesi'nde tamamladı. 1995 yılında Deniz Harp Akademisi eğitimini bitirdikten sonra, Şubat 2000'de Silahlı Kuvvetler Akademisi mezuniyetini 
müteakip kendi isteği ile deniz kurmay yarbay rütbesindeyken emekliye ayrıldı. 2002 yılında İstanbul Barosu'nda da avukatlık stajını tamamlayan Kurumahmut, halen 18 Temmuz 2003 tarihinde atandığı Denizcilik Müsteşarlığı Deniz Ulaştırması Genel Müdürülüğü görevini sürdürmektedir.

Deniz hukuku ve denizde silahlı çatışma hukuku konularında yayınlanmış kitaplarıyla çok sayıda makalesi mevcuttur. Sayın Ali Kurumahmut evli ve bir çocuk babasıdır. Buyurun Sayın Kurumahmut.

ALİ KURUMAHMUT: Sayın Başkan, Denizcilik Müsteşarı Sayın İsmet Yılmaz, Sayın Komutanlarım, Sayın Rektör Yardımcılarım ve değerli konuklar, bugün burada sizlerle beraber olmaktan ve sizlere hitap etmekten duymuş olduğum memnuniyeti öncelikle ifade etmek istiyorum. Ben hocamın biraktığı yerden egemenlik meselesini ana hatlarıyla sizlere sunmaya çalışacağım.

Bildiğiniz gibi Türk-Yunan ilişkileri içerisinde Ege sorunları, özellikle 20. yüzyılın son çeyreğinden itibaren özel bir önem ve önceliğe sahip olmuştur. Ege sorunları analiz edildiği zaman iki önemli nokta dikkat çekmektedir. Bu sorunların -Sayın Başkan'ın da ifade ettiği gibiYunanistan'ın bağımsız bir devlet olarak tarih sahnesine çıtı̆̆ğ 24 Nisan 1830 'a inen ideolojik ve soyut bir geçmişi vardır. Diğer taraftan Türkiye ile Yunanistan arasında başta Ege'de olmak üzere, siyasi ve hukuki bir statü tesis eden Lozan Barış Antlaşması'na inen siyasi ve hukuki bir geçmişi vardır.

Ege sorunları -hocam daha kapsamlı ifade etti, ben bir cümleyle söyleyeceğim- birbirini etkileyen, ilgilendiren, birbirleri arasında nedensonuç ilişkileri bulunan karmaşık bir bütündür. Ancak egemenlik ihtilafı resmiyet kazandıktan sonra bu sorunlarda da ciddi bir değişiklik ortaya çıkmıştır. Çünkü siz egemenlik ihtilafını halletmeden Ege Denizi'nde varolan karasularını sorununu, kıta sahanlığı ve münhasır ekonomik bölgenin sinırlandırılması sorununu halledemezsiniz. Asıl olan toprak egemenliğinin çözümlenmesidir. Buna paralel olarak hava sahası sorunları da hem egemenlik sorununa, hem deniz yetki alanları sorununa bağlı olarak çözülebilecek sorunlardır.

Ege'de egemenlik sorununun çözümü bakımından üç kritik zaman önem arz etmektedir. Bunlardan birincisi Yunanistan'ın bağımsızlığının Osmanlı Devleti tarafından tanındı ̆̆ı ve Yunanistan'ın tarih sahnesine devlet kimliğiyle çıtığı 24 Nisan 1830'dur. Bir diğeri ise Ege'nin hukuki ve siyasi statüsünü belirlemeye çalışan 24 Temmuz 1923 tarihli Lozan Barış Antlaşması'dır. Üçüncü kritik zaman ise Ege'de egemenlik ihtilafının resmiyet kazandığı, sizlerin "Kardak Krizi" olarak bildiğiniz, Kardak Krizi ile sembolleşen 31 Ocak 1996'dır.

Ege'de Osmanlı egemenliği öncesinde bütün ada, adacık ve kayalıklar üzerinde genelde Venedik, Ceneviz ve şövalyelerin bir hâkimiyeti ve idaresi 
söz konusuydu. Osmanlı Devleti Ege hâkimiyet mücadelesine başlayınca karşısında Yunanlılar yoktu. Zaten Yunanistan diye bir devlet yoktu. Osmanlı Devleti, Ege adalarına yönelik hâkimiyet mücadelesini Ceneviz, Venedik ve şövalyelere karşı vermiştir.

1669 y1lında Ege'nin güneyinde yer alan Girit Adası'nın Osmanlı egemenliğine girmesiyle Ege Denizi'nde yer alan bir ada hariç bütün ada, adacık ve kayalıklar Osmanlı egemenliğine girmişti. Hemen orta Ege'den güney Ege'ye batı ulaştırma koridoruna hakim bir yerde bulunan İstendin Adası'nın da 1718 yılında en son olarak Osmanlı egemenliğine girmesiyle Ege denizinde yer alan bütün ada, adcık ve kayalıklar Osmanlı egemenliğine girmiş, Ege Denizi bütünüyle bir Osmanlı iç denizi haline gelmiştir. Bu bir başlangıç noktasıdır. Bundan sonra sizlere sunmaya çalışacağım egemenlik ihtilafına ilişkin tezlerimizin dayanak noktası budur. Bu tarihten sonra Yunanistan'ın bağımsız bir devlet olarak tarih sahnesine çıktığı 24 Nisan 1830 yılına kadar Osmanlı hâkimiyeti kesintisiz devam etmiştir. Bu konuda uluslararası hukukçular arasında bilinen ve görülen herhangi bir ihtilaf mevcut değildir. Dolayısıyla biz bugün Ege'de Yunanistan egemenliğine devredilen adaların hangileri olduğunu açıklarken bu tarihten itibaren ve temelde 24 Nisan 1830'dan itibaren uluslararası hukuk kurallarına göre Yunanistan egemenliğine devredilen adaların hangileri olduğunu bilmemiz gerekir.

Sizlere burada sunacağım, sizlerle paylaşacağım her bilgi belgeye dayanan bilgidir. Ege Denizi'nin statüsünü düzenleyen temel uluslararası antlaşmalara ve düzenlemelere, Osmanlı İmparatorluğu, Türkiye Cumhuriyeti Devleti, Yunanistan ve Avrupa'nın güçlü devletlerine ait siyasi haritalara ve büyük bir bölümü Osmanlı arşivlerinde bulunan ve uluslararası yargı organlarının belge niteliğinde kabul edilebilir olarak gördüğgü arşiv belgelerine dayanan bilgileri sizlerle paylaşacağım. Bunlardan bir tanesi Yunanistan'ın bağımsız devlet olarak tarih sahnesine çıktığı 24 Nisan 1830 'da sonra, 1836 tarihi Osmanlı siyasi haritasıdır. Bu haritada görüleceği gibi Ege'nin batı kısımlarını, Yunanistan kıyılarını göstermektedir. Siyasi sınır çok net olarak gösterilmektedir ve bunun içerisinde kalan ve kuruluşunda Yunanistan'a devredilen adaları, adacıkları ve kayalıkları ismen de sayan çok sayıda Osmanlı ve Yunan belgesi de mevcuttur ve bu siyasi haritadaki bilgileri teyit etmektedir.

1883 Yunan siyasi haritasını yine örnek olarak sizlere sunmak üzere buraya getirdim. Burada tek değişen 1830'dan sonra Yunanistan kıtasındaki genişlemeye bağlı olarak deniz yan sınırının kuzeye kaymış olmasıdır, ada, adacık ve kayalıklarda herhangi bir değişiklik söz konusu değildir.

1897 Osmanl1-Yunan Savaşı'ndan sonra yapılan antlaşmanın eki olan bir başka siyasi harita yine aynı şekilde 1830 'daki toprak statüsü ada, adacık ve kayalıkların statüsü devam etmektedir, yalnız Yunanistan'ın kuzeye 
genişlemesine paralel olarak yan sınır biraz daha kuzeye kaymış görünmektedir.

$\mathrm{Bu}$ örnek olarak sunduğum haritalardan da görüleceği üzere kuruluşundan Ege'de bizim bugün temel olarak aldığım Lozan Barış Antlaşması'na kadar Yunanistan egemenliğine devredilen ada, adacık ve kayalıklar konusunda herhangi bir ihtilaf, bir tartışma bir tereddüt söz konusu değildir. Başlangıçta kuruluşunda, 24 Nisan 1830'da “Kuzey Sport Adaları" olarak isimlendirdiğimiz bu ada grupları, Eğriboz Adası ve Kiklat Adaları olarak sınıflandırdığımız bu adalar Mora Yarımadası ile birlikte Yunan egemenliğine devredilmiştir. 1864 yılında İngiltere, Fransa, Rusya ve Yunanistan arasında yapılan, bir yıl sonra Osmanlı İmparatorluğu ile de teyiden tekrarlanan antlaşma ile Ege'nin batısında yer alan Yedi Adalar olarak bildiğimiz adaları İngiltere Yunanistan'a vermiştir. 1864 ve 1865 yılı antlaşmalarıyla bu Yedi Ada kapsamında bulunan Çuha ve Küçük Çuha adalarının da egemenliği Yunanistan'a devredilmiştir.

Balkan Savaşı'ndan sonra yapılan Londra Antlaşması ile hepimizin bildiğiniz gibi Girit Adası da tekrar Yunanistan'a devredilmiştir. Bundan sonra Ege'de egemenlik devrine ilişkin herhangi bir statü değişikliği söz konusu olmamıştır. Ancak bundan sonra anlatacaklarıma ışık tutacak önemli gelişmeler olmuştur. Trablusgarp Harbi sırasında İtalya, bizim "Menteşe Adaları" olarak isimlendirdiğimiz, Yunanlıların ve kamuoyunun "12 Ada" olarak bildiği ve isimlendirdiği bölgede toplam 16 adayı işgal etmiştir. Daha sonra Sevr Antlaşması'nın -hiçbir zaman yürürlüğe girmemiş ve ölü doğmuş bir antlaşmadır- 122. maddesine, Lozan Barış Antlaşması'nın 15. maddesine ve Paris İtalyan Barış Antlaşması'nın 14. maddesine bu 16 adanın 13'ü konu olmuştur. 18 Ekim 1912 tarihinde akdedilen Ouchy Barış Antlaşması'nın 2. maddesi gereğince İtalya işgal ettiği bu 16 ada üzerindeki işgaline son vermesi gerekiyordu. Yalnız hemen arkasından Balkan Savaşı'nın çıkması ve Balkan Savaşı'ndan sonra Birinci Dünya Savaşı'nın çıkması nedeniyle bu işgal durumu, bu fiili durum sonlandırılmamıştır ve Birinci Dünya Savaşı'ndan sonra Lozan Barış Antlaşması'na nihayetinde bu adalar konu olmuştur.

Yine Trablusgarp Harbi'nden sonra yaşanan Balkan Harbi'nde Yunanistan Ege'nin kuzey-doğusunda bulunan Taşoz'dan Ahıkerya'ya kadar toplam 11 adayı işgal etmiştir. Bu adalar hangileridir? Taşoz, Semadirek, Gökçeada, Bozcaada, Limni, Bozbaba, Midilli, Sakız, İpsara, Sisam ve Ahıkerya adalarıdır. Ama Osmanlı Devleti bu işgali hiçbir zaman tanımamıştır. İtalyan fiili durumunu da tanımamıştır Osmanlı Devleti Lozan Barış Antlaşması'na kadar, Milli Mücadele süresince de bu işgali tanımadığını işlem ve uygulamalarıyla, şartlar müsaade ettiği ölçüde göstermeye çalışmıștır. Neticede Lozan Barış Antlaşması akdedildiği zaman Lozan Barış Antlaşması'na konu olan adalar, egemenliği o zamana Yunanistan'a devredilmiş olan Kuzey Sporat adaları, Eğriboz Adası, Kitlat adaları, Çuha, Küçük Çuha ve Girit dışında kalan ve Ege'nin doğusunda 
bulunan adalardır. Lozan Barış Antlaşması'nın dört maddesi adaların egemenliğine ilişkin düzenleme getirmektedir. Bunlar 6'ncı, 12'inci, 15'inci ve 16 '1nci maddelerdir.

Lozan Barış Antlaşması'nın 12 ile 15'inci maddeleri somut olarak egemenlik devrini düzenlemektedir. 12'inci maddesine göre üç ada 13 Şubat 1914 tarihinde altı büyük devlet kararına dayanılarak, yani o tarihte Yunan işgali altında olmaları nedeniyle 12'inci madde hükmünce egemenliği Yunanistan'a devredilmiştir. Bunlar Taşoz, Bozbaba ve İpsara adalarıdır. Altı ada; Semadirek, Limni, Midilli, Sakız, Sisam ve Ahıkerya adaları ise ismen sayılarak egemenlikleri Yunanistan'a devredilmiştir. Bunun dışında egemenliği Yunanistan'a devredilen bu bölgede herhangi bir ada, adacık ve kayalık mevcut değildir.

Peki devredilmeyen var mıdır? Tabii bu ölçekteki bir haritada küçük adacık ve kayalıkları görmek teknik olarak zor ve imkânsızdır. Mesela bu egemenlik konusunu sembolize eden Kardak kayalıklarını burada göremiyoruz. Ama bu bağlamda Semadirek adasının altı mil doğusunda bulunan Zürafa kayalıkları, Sakız adasının doğusunda bulunan Koyun adaları grubu -burada Koyun Adası, Taşa, Vaton ve Gaveta adaları- müstakil adaları oluşturmaktadır. Bunun yanında egemenliği devredilmeyen toplam 14 ada, adacık ve kayalık vardır.

Ege'nin hemen ortasında, şu bölgede bulunan ve daha sonra sunacağım bir haritada görüleceği üzere yer alan Venedik kayalıkları hiçbir zaman egemenlik devrine konu olmamıştır. Yine Sisam ile Ahırkerya arasında yer alan iki büyük ada ve etrafında toplam 19 adacık ve kayalıktan oluşan Hürşid ve Fornoz grubu adalar; bunlar da egemenlik devrine konu olmamıştır.

Menteşe adaları bölgesinde ise toplam 13 ada ve tâbi adacık egemenlik devrine konu olmuştur ve bunların egemenliği İtalya'ya devredilmiştir. Daha sonra Türkiye Cumhuriyeti Devleti ile İtalya arasında herhangi bir şekilde tâbi adacık kavramına ilişkin herhangi bir antlaşma veya müzakere gerçekleşmemiştir. Zaten bu adalar daha sonra Türkiye Cumhuriyeti Devleti'nin taraf olmadığı Paris İtalyan Barış Antlaşması'yla da İtalya'dan alınıp Yunanistan'a devredilmiştir. Ancak bizim bu konuya ilişkin yaptı̆̆ımız teknik çalışmalar, özellikle İngiliz ve Amerikalıların yaptı̆̆ 1 çalışmalarla büyük ölçüde paralellik arz etmektedir. Mesela size sunmuş olduğum bu harita 1943 yapımı bir İngiliz ipek haritasıdır. İngilizler bu haritayı gösterirken, bakınız şu bölgeyi İtalyan bölgesi olarak göstermektedirler. Ve onlar da Lozan Barış Antlaşması'nın 15'inci maddesinde yer alan "tâbi adacık" kavramına kendilerince bir teknik ve hukuki bir yorum getirerek, çok sayıda ada, adacık ve kayalığın Türkiye Cumhuriyeti Devleti'ne ait olduğunu bu haritayla teyit etmişlerdir. 
Benzer bir harita 1951 tarihli Amerikan haritasıdır. Birinci haritanın özelliği Lozan'ın 15'inci maddesinde yer alan tabii adacık kavramına bir teknik yorum getirilerek yapılan bir haritadır. Bu ise Paris-İtalyan Barış Antlaşması'nın 15'inci maddesinin teknik yorumu neticesinde hazırlanmış bir haritadır. İki harita arasında da paralellik vardır ve çok sayıda, bu bölgede Kardak kayalıkları dâhil, çok sayıda ada, adacık ve kayalı̆̆ı 1951 yılında Amerikalılar Türkiye Cumhuriyeti Devleti'nin egemenliğinde olduğunu teyit edercesine göstermektedirler.

Şimdi bu bölgede ismen sayılan 13 ada ve bunlara tâbi veya bitişik adacıkların dışında çok sayıda müstakil ada ve adacık ve kayalık mevcuttur. Bizim yaptığımız değerlendirmelere göre hemen burada etrafında 14 tane ada, adacık ve kayalık bulunan Eşek Adası, hemen şurada 21 ada, adacık ve kayalıkla Nergis Adası ve Nergis Grubu var. Sonra şuraya geliyoruz başlangıçta size gösterdiğim siyasi haritaları bir düşünün- burada Koçbaba, Ardıççık ve Kendiröz diye üç tane ada ve etrafında adacık ve kayalıklar grubu bulunmaktadır. Bunlar da hiçbir zaman egemenlik devrine konu olmamıştır ve bu şekilde çok sayıda ada, adacık ve kayalığın egemenlik devrine konu olmadığını görüyoruz.

Bizim Sayın Prof. Başeren ile birlikte çok geniş bir akademisyen grubunun katkılarıyla yaptığımız çalışmada somut olarak 152 ada, adacık ve kayalığın egemenliğinin Yunanistan'a uluslararası antlaşmalarla, uluslararası hukuk kurallarıyla devredilmediğini gördük ve tespit ettik. Bu 152 ada, adacık ve kayalığın Ege'de -herhalde biraz sonra Sayın Başeren bahsedecektir- sahip olduğu karasuyu alanı Ege'nin yaklaşık yüzde altısıdır. Yani bugün Yunanistan'ın Türkiye'ye mubah gördüğü yüzde yedilik karasuları alanına sadece egemenliği devredilmemiş bu ada, adacık ve kayalıkların karasuları alanı hemen hemen eşit bir alana sahiptir.

Bunları da üç gruba ayırmak mümkündür. Egemenlik ihtilafının resmiyet kazandığı Kardak krizi öncesinde bu adalardan bir grubu meskûndu, yani Yunan idari tasarrufu altındaydı. Bir grubu meskûn olmamakla birlikte üzerinde fener, tesis, inşa faaliyetleri vardı. Bir grubu ise, Kardak kayalıkları gibi gayrı meskûndu. Ancak 1996'dan sonra Yunanistan özellikle gayri meskûn olan ve Türkiye sahillerine yakın bulunan ada ve adacıklar üzerinde bir fiili durum üstünlüğü oluşturmaya yönelik çok ciddi bir yapılanmaya gitmiştir. Asker çıkarmıştır, bayrak dikmiştir, helikopter pisti inşa etmiştir ve ağır silah, telsiz cihazları yerleştirmiştir. Bu faaliyetler herhalde, biz tabii bunları takip edemiyoruz, ama Yunan medyasından izleyebildiğimiz kadarıyla bugün de devam etmektedir.

Bizim değerlendirmelerimize göre egemenliği antlaşmalarla Yunanistan'a devredilmeyen ve 31 Ocak 1996 Kardak kriziyle sembolleşen bu 152 ada, adacık ve kayalık konusunda o günden bu güne kadar yapılaması gerekirken yapılmayan, yapılmaması gerekirken yapılan işlem ve uygulamalar olmuştur. Bunda diplomasimizden akademisyenlerimize ve 
sokaktaki vatandaşımıza kadar herkesin mesuliyeti vardır. Ancak şunu özellikle ifade etmek istiyorum: 1996 yılında Türkiye'nin önüne tarihi bir fırsat çıkmıştır, zemin kazanmıştır. Ancak o tarihten sonra, işte bu yapılmayanlardan ve yapılmaması gerekirken yapılanlardan dolayı bu inisiyatif kaybedilmek üzeredir ve zemin de kaybedilmek üzeredir. Bunun için biz, belki biraz duygusal bu işe gönül vermiş, ömür vermiş insanlar olarak, bu 152 ada, adacık ve kayalık için "Unutulan Türk Adaları" ismini kullanıyoruz. Ama şunu da her platformda söylemekten imtina etmiyoruz: Gelecek nesiller unutanları affetmeyecek ve sorgulayacaktır.

Hepinize saygılar sunuyorum.

PROF. DR YAVUZ ERCAN (OTURUM BAŞKANI): Teşekkür ederim Sayın Kurumahmut. Birinci oturumun son konuşmacısı Sayın Prof. Dr. Sertaç Başeren. Sayın Başeren'in özgeçmişini biraz önce okumuştum, dolayısıyla tekrar etmemize gerek yok. Onun için konuşmanıza başlayabilirsiniz Sayın Başeren, buyurun...

PROF. DR. SERTAÇ BAŞEREN: Teşekkür ederim efendim. Bu güzel tebliğlerden sonra konuşmak gerçekten zor olacak. Sabrınızın da tükendiğini biliyorum, ama ben de sizlere hitap etme şansımı iyi değerlendirmeye çalışacağım.

Karasularını anlatacağım size, ama derli toplu bir değerlendirme yapmak ve belki de tutumumu, duruşumu göstermek için şöyle bir cümleyle başlamak istiyorum. Ege sorunlarının temelinde Yunanistan'ın revizyonizmi vardır. Her şeyi tepe taklak etmek istemeleri yüzünden sorun ortaya çıkıyor. Lozan Barış Antlaşması ile kurulmuş bir denge var. Yunanistan bu Lozan dengesini başından sonuna kadar değiştiriyor. Hocam anlattı, silahsızlanmış adaların statüsünden bahsetti.

“Adalar silahsızlandırılmış olmasın!” İyi, peki...

Kıta sahanlı̆̆ı... “O da benim olsun!”, İyi, peki, o da tamam...

"Adalar da benim olsun, karasuları da benim olsun, Ege benim olsun!" diyor... Bunu demeye getiriyor, Lozan dengesini her noktada değiştirmeye çalışıyor. Bunun adı revizyonizmdir. Kıta sahanlığı konusu için de aynı şeyi söyledim. Diyeceksiniz ki: Kita sahanlığı kavramı devletler hukukuna 1945 'de girdi, Lozan dengesi ile ne ilgisi var?

Var... Lozan Barış Antlaşması yapıldığı zaman her iki devletin de karasuları genişliği üç mildi. Çok geniş bir açık deniz alanı iki devletin kullanımına bırakılmıştı. Bu Lozan dengesinin bir parçasıdır. Türkiye'ye hiç kıta sahanlığı bırakmayacak şekilde Ege kıta sahanlığını sahiplenmek, Türkiye'nin kıta sahanlığına ilişkin haklarını elinden almak bu dengeye aykırıdır. Karasuları konusunda da durum tamamıla böyledir ve bu çerçevede anlatılması gerekir. Uluslararası antlaşmaları yapıldığı koşulların 
unsurları dikkate alınarak yorumlamak icap eder. Lozan Barış Antlaşması'nda karasuların genişliğine ilişkin bir hüküm yoktur. Bununla beraber, Lozan Barış Antlaşması yapıldı̆̆ında her iki devletin de karasuları genişliği üç mildi ve Lozan Barış Antlaşması'na bunun yansımaları da olmuştur.

Yunanistan ilk defa 1931'de karasularının genişliğini hava polisliği maksadıyla10 mile çıkarttı. Bir kraliyet kararnamesiyle; "karasularımın genişliği, hava polisliği maksadıyla 10 mildir” dedi. Bu karasularına doğrudan pratik sonuçlar doğuran bir düzenleme değildi, ama ben hava uyuşmazlıklarından da bahsedeceğim, dolayısıyla şimdiden bundan da söz etmekte bir mahsur görmedim.

Daha sonra 1936 yılında karasularının genişliğini altı mile çıkarttı. Bu aslında hukuka aykırı bir durumdu, biz buna itiraz etmeliydik. Bunu maalesef yapmadık. Tam aksine seneler sonra 1960'da 476 sayılı Karasuları Kanunu ile biz de karasularımızın genişliğini altı mile çıkarttık. Tabii bu Yunanistan'ın itirazlarına konu oldu, ama karasularını 12 mile çıkartma arzusuna engel olamadi.

Yunanistan III. Deniz Hukuku Konferansı'na katılmış, sözleşmeyi imzalamış, onaylamış ve taraf olmuştur. Türkiye de 1982 Sözleşmesi'nin yapılmasına katılmış, katkılarda bulunmuş, ama taraf olmamıştır. Sözleşmenin üçüncü maddesinde karasularının en çok 12 mile kadar genişletilebileceği öngörülmektedir. Yunanistan diyor ki: "Karasularına 12 mile genişletmek benim hakkımdır ve ben bu hakkımı zamanı gelince kullanacağım”.

Karasularının 12 mile genişletilmesi nasıl bir tablo ortaya çıkartır? Hemen bunun üzerinde konuşmaya başlayalım.

Şurada gördüğünüz harita altı mil karasuları genişliği esas alınarak çizilmiş bir haritadır. Şu gördüğünüz pembeler, bunlar biraz önce arkadaşımın anlattığı egemenliği Yunanistan'a devredilmemiş ada, adacık ve kayalıklar ve onların karasularıdır. Bunların toplam yüzölçümleri Ege Denizi'nin tamamının, yani karasuları kaplama alanlarının yüzölçümleri Ege Denizi'nin toplam yüzölçümünün yüzde beşi kadardır. Türkiye'nin karasuları kaplama alanları toplamı yüzde yedidir. Yunanistan'ın da yüzde 38'dir. Bu tablodan 12 mil genişliğinde karasularına yer verilen şu ikinci haritanın ortaya koyduğu tabloya geçmek istiyorum. Bu ikinci haritaya bakınca, Yunanistan'ın karasularının kaplama alanlarının yüzde 60'a ulaştığını görüyoruz. Türkiye ise sadece yüzde 8.76 'da kalmaktadır. İsterseniz yüzde 9 deyin. İşte Türk kamuoyunda savaş sebebi diye bilinen konu budur. Egemenliği devredilmemiş ada, adacık ve kayalıklarınki ise yüzde 10'dur. 1995 yılında Yunanistan'ın; "Ben karasularımı 12 mile çıkartacağım" demesi üzerine Türkiye Büyük Millet Meclisi 8 Haziran 1995'de aldığı bir kararla askeri tedbirlerin de dâhil olduğu her türlü tedbiri 
alma yetkisini hükümete vermiştir. Bu savaş sebebi olarak bilinir ve çoğu zaman uluslararası hukuka aykırı olduğu ithamlarına maruz kalır. Ben şimdi size sorarım: Yine biraz önce konuşuldu, Hocam anlattı; biz Ege Ordusu'nu kurduk diye Yunanistan meşru müdafaa halinde kalıyor da, biz; "Şu tablodan kurtulmak için kuvvet kullanırız" dersek bu uluslararası hukuka niçin aykırı oluyor!

"Meşru müdafaa" kavramı oldukça konuşulan, çok tartışma götüren bir kavramdır. Bunun çok geniş yorumları da var. Ben size şöyle bir şey söyleyeyim: Yunanistan'ın şu genişleyen karasuları nerede genişliyor? Şu tabloya bir bakalım. Bakın nerede genişliyor: Midilli Adası'nın batısına doğru gittiği zaman Anadolu kıtasının doğal uzantısı üzerinde genişliyor. Şuradan 12 mile çıktığı zaman yine Anadolu kıtasının doğal uzantısı üzerinde genişliyor. Bu doğal uzantıyı Sayın Hocam biraz önce kıta sahanlığ 1 olarak takdim etti. Doğrudur, öyledir de. Her devletin denizaltındaki uzantısı ona ait kıta sahanlı̆̆ını oluşturur. Yunanistan'ın karasularını 12 mile çıkartması -yani şu tabloya geri dönelim- Türkiye Cumhuriyeti'nin kıta sahanlığını elinden alacaktır. Bu sadece hakkın suiistimali mevzuu olarak görülmemelidir. Biliyorsunuz Yunanistan kıta sahanlığı konusunun çözülmesiyle ilgili olarak 1974'de tek taraflı olarak Uluslararası Adalet Divanı'na müracaat etti. Orada Uluslararası Adalet Divanı Yunanistan'ın 1928 genel senedinde ülkesel mevzuları çekince ile divanın yargı yetkisi dışında tuttuğunu belirterek davayı ret etti. Yani kıta sahanlığını ülkesel mevzular içinde gördü. Ben size diyorum ki: Yunanistan kıta sahanlığını, Yunanistan karasularını 12 mile çıkartarak Türkiye Cumhuriyeti'nin kıta sahanlığını, yani divanın ülkesel yetkiye tabii dediği yerleri Türkiye'nin elinden almaktadır, egemenlik hakları uyguladığı yeri elinden almaya çalışmaktadır. Bu olabilir bir iş midir? Hayır, bu olamaz bir iştir. Ama bu durum, öyle sanıyorum ki, şu savaş sebebi diye bize söylenen, çok da tenkit edilen meselenin ne kadar haklı olduğunu göstermektedir.

Karasuları ile ilgili meseleleri, karasularının genişliği meselesi, adaların karasuları meselesi ve sinırlandırma meseleleri altında toplayabilmek mümkündür. Önce karasularının genişliği konusu üzerinde biraz konuşalım istiyorum.

Yunanistan karasularının genişliği konusunda evrensel olarak tek bir kural olduğunu, bunun da karasularının genişliğini 12 mil olarak öngördüğünü ve bir örf ve adet hukuku kuralı oluşturduğunu, dolayısıyla bunun Türkiye'yi de bağladığını söylemektedir. Karasularının genişliği konusunda Yunanistan'ın temel tezi budur.

Buna karşılık Türkiye ne diyor? Türkiye diyor ki: "Karasularının genişliği ile ilgili genel bir kural yoktur".

Birleşmiş Milletler Deniz Hukuku Sözleşmesi'nin üçüncü maddesinde karasularının en çok 12 mile kadar genişletilebileceği söylenmektedir. 
Öncelikle Türkiye bu sözleşmeye taraf değildir. Madde hükmünün ifade tarzından duruma bağlı olarak daha az genişlikte karasularının söz konusu olabileceği hallerin varlığı da anlaşılmaktadır. Yine Türkiye, Ege gibi yarı kapalı bir denizde karasularının 12 mil olarak uygulanamayacağını söylemektedir. BMDHS md. 3 hükmünün örf ve adet hukuku kuralı olduğu iddiası karşısında da Türkiye'nin sürekli itiraz eden devlet statüsünü kazanmış olduğunu söylenmektedir. Öyledir de...

Belki burada bir noktaya değinmek gerekir. Ayrıntı gibi durur ama benim önemsediğim bir konudur. Türkiye Cumhuriyeti'nin karasularının genişliği yürürlükte olan 2674 sayılı yasamız ve onu birkaç gün izleyen, birkaç gün sonra alınan bir Bakanlar Kurulu kararnamesi çerçevesinde değerlendirilebilir; Ege'de altı mil, Karadeniz ve Akdeniz'de 12 mil olarak uygulanmaktadır. Yazılı metinlere bakıldığı zaman Türkiye Cumhuriyeti'nin karasuları genişliği altı mildir. Karadeniz ve Akdeniz'de 12 mile ilişkin bir uygulama var mı? Var. Ama bunun opinio juris'i yani bu bir hukuk kuralı değil.

Bunun üzerinde şu sebeple duruyorum; Yunanistan Türkiye'ye diyor ki: “Mademki 'sürekli itiraz eden devlet statüsündeyim' diyorsun, öyleyse bu söyleminle tutumunun da paralel olması lazım. Karadeniz ve Akdeniz'de 12 mil uygulayarak, 12 mil genişliğinde karasuları örf ve adet hukuku kuralı karşısında sürekli itiraz eden devlet olunamaz" diyor.

Bunun çok pratik bir cevabı var. Türkiye Cumhuriyeti'nin karasularının genişliği 6 mildir. Uygulama 12 mil olmuş mudur? Evet, olmuştur, ama bu sadece uygulamadır. Bunun hukuk kuralı olması için gerekli olan opinio juris mevcut değildir.

Adalar mevzu üzerinde biraz konuşalım. Çünkü Ege'deki sorun, doğrusunu isterseniz şöyle kuzeyden güneye doğru bir ortay hat düşünün, bu ortay hattın ters tarafındaki adalardır. Şöyle kuzeyden güneye doğru bir ortay hat düşünürsek, bunun ters tarafındaki doğu Ege adaları, Anadolu sahillerinin önündeki doğu Ege adaları, Ege sorunlarının temelinde yatmaktadır. Bu sebeple ben de Sayın Hocamın izlediği yolu takip ediyorum, demişti ki: Kıta sahanlığı mevzu adalarla bağlantılı olarak ortaya çıkan bir sorundur. Karasuları bakımından da durum aynıdır.

Adaların karasuları var mı, yok mu? Bunu tartışalım. Yunanistan ülkesel bütünlük tezini ileri sürerek diyor ki:

“Tıpkı kara parçaları gibi adaların da karasuları vardır. Bunlar Yunan ülkesinin birer parçasıdır. Bunlar da bizim ülkemizdir, dolayısıyla onların da karasuları vardır." Yunanistan bundan başka III. Deniz Hukuku Konferansı'nda bir ara takımada devleti statüsünden yararlanmaya çalıştı. Takımada devleti statüsüyle yapılmak istenen şuydu: En dıştaki adaların en dış noktalarını birleştirerek içerde kalan suların hepsini takımada suları, yani egemenliğine tabii sular haline dönüştürmek düşüncesiydi. Bunu yapmaya 
çalıştı, fakat sonra konferans boyunca sadece adalardan oluşan devletlerin, ülkesi sadece adalardan oluşan devletlerin takımada devleti olabileceği kabul edilince bu tezinden vazgeçti. Ama ülkesel bütünlük tezi çerçevesinde adaların da kara parçaları gibi karasuları olduğunu savunmaya devam etti.

Buna karşı söylenecekler var tabii. Her şeyden önce adaların kıta sahanlığı ve münhasır ekonomik bölgesi ile ilgili hükümlerden bahsedelim. Bunlar kendisine ait bağımsız, ekonomik yaşantısı olmayan, üzerinde insan yaşamayan ada, adacık ve kayalıkların kıta sahanlığı ve münhasır ekonomik bölgesi olmayacağını öngörmektedir. Adaların deniz yetki alanlarına böyle bir istisna getirildikten sonra aynı durumu karasuları için de düşünmemenin hiçbir nedeni yoktur. Biz bu koşullardaki adaların da karasuları olmayacağı veyahut da daha az karasuları olabileceği düșüncesindeyiz. Bu sadece bizim, benim ya da Türkiye'deki akademisyenlerin ileri sürdügüu bir görüş değil. Bu husus kuzey denizi kıta sahanlığı davalarında ve hakem mahkemesinin İngiltere ile Fransa arasındaki Manş Denizi adaları uyuşmazlığı ile ilgili olarak verdiği kararlarında da hükme bağlanmıştır. Her adanın sırf ada olması sebebiyle deniz yetki alanlarına da sahip olabileceğini savunmak mümkün değildir.

Bir başka uyuşmazlık konusu karasularının genişliğini belirleme yetkisi üzerinedir. Yunanistan diyor ki: "Karasularının genişliğini tek başına ve tümüyle ben belirlerim. Kıyı devleti olarak Yunan karasularının genişliğini ben belirlerim" diyor.

Kıyı devletinin karasularının genişliğini belirleme yetkisine sahip olduğu doğrudur, ama diğer devletler bakımından bunun geçerliliği, onların bunu tanımasına bağlıdır ve kabul etmesine bağlıdır. Öbür taraftan yarı kapalı denizler bakımından karasularının genişliğini tek başına kıyı devletinin belirlediğini düşünmek doğru da değildir. Yarı kapalı denizlerde bu belirleme taraflarca müştereken yapılabilir. Ve tabii Yunanistan "Ben karasularımın genişliğini belirlemede mutlak bir takdir yetkisine sahibim", yani "Ben bunu istediğim gibi yaparım" diyor. "Bu genişliği belirlemek benim elimdedir" diyor.

Bunun da doğru olduğunu kabul etmek mümkün değildir. Öncelikle Birleşmiş Milletler Deniz Hukuku Sözleşmesi'nin üçüncü maddesine çok fazla itibar edilir. Hemen bununla ilgili daha önce söylediklerimi hatırlatayım:

"Karasularının genişliği mutlak olarak 12 mildir" demiyor, "12 mile kadar genişletilebilir" diyor. Hüküm içinde daha az karasularına sahip olunabilecek durumların varlığını da muhafaza etmektedir.

Kapalı ve yarı kapalı denizlerde bu genişlik hakça ilkeler çerçevesinde belirlenmelidir. Öbür taraftan hiçbir devletin bir başka devletin açık denizle ilişkisini, münhasır ekonomik bölgeyle ilişkisini kesme hakkı yoktur. Ayrıca bir başka bağlamda konuştuğumuz mevzua da değinmek gerekir. Yunanistan 
karasularını genișletecek olursa, bunu Türk kıta sahanlığı üzerinde genişletecektir, Türkiye'nin kıta sahanlığını elinden alarak genişletecektir. $\mathrm{Bu}$ hakkın suiistimali anlamına gelir ve mümkün değildir. Öbür taraftan kıta sahanlığına ilişkin hukuk kuralları da bunun yapılmasına izin vermez.

Bir başka konu -yine hep karasuları uyuşmazlığı içerisindeyiz- bir başka alt başlık karasularının sınırlandırılması mevzuunda ortaya çıkar. Yunanistan karasularının sınırlandırılmasında doğu Ege adalarının Anadolu sahillerine en yakın olanlarıyla Anadolu sahilleri arasında ortay hattı öngörmektedir. Bu tezi savunuyor. Türkiye'nin tezleri nedir? Bunun üzerinde konuşmadan evvel derhal şunu söyleyelim: Öncelikle Ege'de çizilmiş bir sınır yoktur. Ege'de sınırın olmaması önem taşıyor. Onun için bunu bir kesin tespit edelim istiyorum.

4 Ocak 1932 tarihinde İtalya ile Türkiye arasında çizilmiş bir sınır var. Meis Adası civarında. Sonradan İtalya halefiyeti sebebiyle bu sınır Türkiye ile Yunanistan arasında da geçerli olmuştur. Bütün Ege'de karasuları, karşılıklı sahiller arasında karasuları sınırı adına çizilmiş tek sınır budur. Bir de şurada kuzeyde bir yan sınır var. Onunla ilgili problemler de var. Onun üzerinde de belki konuşabiliriz. Ama asıl mesele Ege'de sınırın olmadığıdır. Ege'de sınır yoksa karasularının sınırının çizilmesi meselesi nasıl olacak? Bunu şimdi konuşabiliriz.

Ege'de karasularının iki çeşit sınırından bahsedilebilir. Birincisi; Midilli Adası'nın batısını düşünün, en tipik olarak burada görülüyor. Burada Türk kıta sahanlığı ile Yunan karasuları arasında bir sınırlandırma konusu söz konusu olacaktır. Çünkü adanın batısında Türkiye'nin kıta sahanlığı vardır. Kıta sahanlığına ilişkin hukuk diyor ki:

"Kıta sahanlığına ilişkin haklar kıta sahanlığı hukukunun meriyete girdiği andan itibaren ve kendiliğinden kıyı devletine aittir”.

Kıta sahanlığına ilişkin hukuk kurallarının yürürlüğe girişi 1945 gibi düşünsek, Truman bildirisiyle, 1945'den beri Anadolu sahillerinin doğal uzantıları Türkiye'ye ait. Bize ait olan egemenlik hakları kullandığımız alan üzerinde Yunanistan'ın karasularını batıya doğru genişletmesi söz konusu olacaktır. Bu kabul edilemez bir durumdur.

Öbür taraftan karasuları arasındaki örtüşme esasında, Midilli’nin doğu sahili açısından konuyu düşünelim. Birleşmiş Milletler Deniz Hukuku Sözleşmesi'nin, 3'ncü Sözleşme'nin 15'inci maddesi dikkate alındığında; özel koşullar başka türlüsünü haklı göstermiyorsa sınır ortay kat olacaktır. Adaların bizzat buradaki mevcudiyeti özel durumun varlığına işaret etmektedir. Öyleyse alternatif sınır burada geçerli olmalıdır, ortay hat değil. Peki, alternatif nedir?

Alternatifi söyleyeyim: Alternatif bizim 1936'da Yunanistan'ın karasularını genişletmesine itiraz etmeyerek kaybettiğimiz husustur. Bu 
adaların özel koşul sebebiyle ana kıtaya bakarak daha az karasuları olmalıdır ve ana kıtada altı milse, burada üç mil olmalıdır. Ben böyle düşünüyorum. Bugün Ege'de bir karasuları sorunu varsa, o sorun bence şöyle olmalıydı: Yunan karasularının altı milden üç mile çekilmesi sorunu olmalıydı. Tersini tartışıyoruz; altı milden 12 mile Yunanistan nasıl çıkmasın? Bunu tartışıyoruz. Ben de size diyorum ki; hukuk normları bakımından, kurallar bakımından baktığınızda şuradaki, adaların, doğu Ege adalarının sınırlandırma esasında karasularının bugünkünün altına çekilmesi mümkündür. "Bunun örnekleri var mı?" denilebilir, akla böyle bir soru gelebilir. Pek çok örneği vardır. Hemen aklıma geleni söyleyeyim. Avustralya Yeni Gine-Papua arasındaki sınırlandırma bunun tipik bir örneğidir ve buna benzer şu elimdeki çalışmada en az on kadar sınırlandırma sayılmaktadır.

Son olarak bir de şu yan sınırla ilgili meselelerden bahsedeyim. Yan sınırla ilgili, kuzeydeki yukarıdaki sınırdan bahsetmiştim, burada bir yan sınır var, ama yan sınır Lozan Barış Antlaşması ile çizilmiş değildir. Lozan Barış Antlaşması'nda sınırı çizeceği öngörülen sınır komisyonuna ilişkin düzenleme işletilmiş ve komisyon kurulmuştur. Bu komisyonun yaptığı bir sinırlandirma var.

Öncelikle bir istikamet konusu var. Meriç nehrinin Talveg hattının genel istikameti geriye doğru ne kadar mesafeyi dikkate aldığınıza bağlı olarak değişecektir. Burada bir farklılık var. Sınır komisyonunun raporunda ekli haritayla bu komisyon raporunda tarif edilen sınır arasında farklılıklar bulunmaktadır. Bunu söylemekte yarar var. Komisyon raporunda deniz sınırının mille hesap edildiği, fakat milin de 1600 metre olduğu hüküm altına alınmıştır. Oysa deniz mili 1800 metredir. Burada bir tutarsızlık var. Ve karasularının genişliği o dönemde üç mildi, şimdi altı mildir. Bu noktada da karasularının sınırlandırılması konusunda yetersizlikler bulunmaktadır.

Teşekkür ederim.

PROF. DR. YAVUZ ERCAN (OTURUM BAŞKANI): Ben de size teşekkür ediyorum Sayın Başeren.

Panelin ilk oturumu burada sona eriyor. İkinci oturumumuzda konuşmacılar daha kısa konuşacak ve arkasından soru-cevap kısmı gelecek, böylece panelin tümü tamamlanmış olacak.

MURAT HASIPEK: Efendim panelimize katılmayıp, Sayın Rektörümüz Prof. Dr. Nusret Aras'a özür telgrafı çekenleri arz ediyorum. Osman Nuri Filiz, Ak Parti Denizli Milletvekili; Bihlun Tamaylığlu, Cumhuriyet Halk Partisi Genel Sekreter Yardımcısı; Türkan Mıcoğulları, Cumhuriyet Halk Partisi İzmir Milletvekili, Ramazan Can, Kırıkkale Milletvekili; Feridun Ayvazoğlu, Çorum Milletvekili; Dengir Mir Mehmet Fırat, AK Parti Genel Başkan Yardımcısı, Mersin Milletvekili; Mesut Özakcan, Cumhuriyet Halk Partisi Aydın Milletvekili; Vahit Erdem, 
Kırıkkale Milletvekili; Akif Gülle, Amasya Milletvekili AK Parti Genel Başkan Yardımcısı; Mehmet Boztaş, Aydın Milletvekili; Yılmaz Ateş, Ankara Milletvekili; Mehmet Elkatmış, Nevşehir Milletvekili, Türkiye Büyük Millet Meclisi İnsan Hakları Komisyonu Başkanı; Nail Kamacı, Cumhuriyet Halk Partisi Antalya Milletvekili; Abdürrahim Aksoy, Bitlis Milletvekili; Mustafa Elitaş, Kayseri Milletvekili; Enver Öktem, İzmir Milletvekili; M. Akif Hamza Cebi, Trabzon Milletvekili; Abdülkadir Ateş, Gaziantep Milletvekili, Avrupa Konseyi Parlamenter Meclisi Siyasi İlişkiler Komisyonu Başkanı arz ederim efendim.

PROF. DR. YAVUZ ERCAN (OTURUM BAŞKANI): İkinci oturumun ilk konuşmacısı Sayın Ali Kurumahmut. Buyurun Sayın Kurumahmut, söz sizin.

ALİ KURUMAHMUT: Teşekkür ediyorum. Bu Yunanistan ile olan ilişkilere bazen kendimi fazla kaptırıyorum. Yakın bir dostum, güvendiğim bir simayla karşılaştığım zaman onların eleştirilerine dikkat ediyorum ve diyorum ki; akademisyenler gibi, akademik kimliğim de var, biraz ileri, biraz geri, biraz ortadan konuşmak herhalde daha uygun ama, yine de kendimi bazı hakikatleri, inandığım değerleri söylemekten alıkoyamıyorum.

Bu son bölümde farklı bir konuşma yapmayı düşünüyorum. Doğrusu buraya gelirken bunu planlamamıştım, ama birinci bölümün sonunda bunları konuşmayı planladım.

Birincisi: Yunanistan devlet kimliği kazandığı tarihten bu güne kadar ülkesini, bizim tespitlerimize göre Türkiye Cumhuriyeti Devleti, Osmanlı Devleti veya Türk milleti aleyhine üç kat genişletmiştir. Dokuz kat deniyor, yedi kat deniyor, ama bizim verilerimize göre bir üç kat genişleme söz konusudur ve milli mücadele hariç Yunanistan taarruz stratejisi ve politikası izlemiştir ve başarılı olmuştur. Bazı tespitlerimi sizlerle paylaşmak istiyorum.

Yunanistan ulus devlet kimliğini Osmanlı Devleti ve Türkiye Cumhuriyeti aleyhine verdiğgi mücadeleler neticesinde kazanmıș veya güçlendirmiş ve kuvvetlendirmiş değildir. Yunanistan başta İngiltere, Fransa ve Rusya olmak üzere batılı devletlerin ürettiği, ortaya çıkardığı bir devlettir ve burada özellikle Fransa ve Rusya'nın desteğinin ötesinde İngiltere'nin bir hamiliği söz konusudur. Belgeler bunu söylemektedir.

Yunanistan ile olan ilişkiler konusunda da bugün için ders alabileceğimiz enteresan gelişmeler olmuştur. Bunlardan bir tanesi 13 Şubat 1914 tarihinde Yunanistan hükümetine, 14 Şubat 1914 tarihinde de Osmanlı Devleti'ne tebliğ edilen altı büyük devlet kararıdır. Nedir bu karar? Balkan Savaşı'ndan Yunanlılar 11 Osmanlı adasını işgal edince bu işgal Osmanlı Devleti tarafından tanınmamıștır. Sonunda 17-30 Mayıs 1329'da, yeni tarih olarak 1913 tarihinde imzalanan Londra Antlaşması'nın dördüncü maddesiyle ve siyasi baskılar neticesinde altı büyük devletin hâkimliği kabul 
edilmiş ve altı büyük devlet kararını vermiştir. Bu devletler Gökçeada ve Bozcaada hariç, o tarihte Yunan işgali altında olan adaların tümünü Yunanistan'a devri kararını verirler ki, burada bir adalet ve hakkaniyetten söz etmek mümkün değildir.

Diğer taraftan -yine konuşmamda bahsetmiştim- Yunanistan bağımsızlığını kazandıktan 34 yıl sonra yine İngiltere'nin kendisine sunduğu yedi adayı egemenliğine dâhil etmiştir. Bu arada öncelikle birinci kuşak adalar olarak nitelendirdiğimiz Kuzey Sporatlar'dan batıdaki Korfu Adasına kadar bütün adalar üzerinde egemenlik tesis etmiş ve bir stratejik hat tesis etmiştir.

Yine Sevr Antlaşması müzakerelerinin uzamasına neden olan önemli bir gelişme olmuştur. Gerek Birinci Dünya Savaşı sırasında, gerekse Sevr'in görüşüldüğüu ve oluşturulduğu Paris Konferansı sırasında Yunanlılar İtalyan işgalinde olan güneydeki 16 adayı da açıkça İtalya'dan istemektedirler. Zaten bu Yunanlılar 19. yüzyılın ikinci yarısında bu kesimi, bu bölgeyi hedef olarak seçmişlerdir ve önce adını değiştirmişlerdir. Demişlerdir ki: "Burası 'Dodecanisos", yani "12 Adadır". Hâlbuki 300-350 yıllık Menteşe Adaları bölgesidir. Ama onların o tarihte hedef olarak seçtiği adalar, meskûn olan adalar, Rodos ve 12 Ada ve bunları Paris Konferansı'nda ve Birinci Dünya Savaşı'nda istemektedir.

Hatta Venizelos -orijinal metnine de ulaştık- Paris Konferansı'na üç sayfalık bir not sunar. Der ki: "Ben batı Anadolu'yu istiyorum, ama batı Anadolu'nun güvenliği bakımından çok önemli olan ve batı Anadolu'yu kuzeyden güneye, böyle bir dizi halinde kapatan tüm adaları da istiyorum".

Yani Venizelos bugün bizim savunmakta olduğumuz tezi Paris Konferansı'nda savunmuştur ve bunun yazılı belgesi mevcuttur. Yani bu bölgeye egemen olan devletin bu adalara sahip olması gerektiği burada da çeşitli vesilelerle izah edilmiştir.

Daha da önemlisi Sevr müzakereleri uzar gider. Uzamasının nedenin Bonin ile Venizelos arasında yapılan görüşmelerdir. Görüşmenin konusu İtalyan işgali altındaki adalardır. Sonunda mutabakata varılır. Antlaşmanın birinci maddesiyle İtalya Rodos ve -bu haritada görülmüyor- Meis hariç diğer adalar üzerindeki egemenliğinden Yunanistan lehine feragat eder. Hâlbuki o tarihte bir egemenlik söz konusu değildir, adalar onların işgali altındadır. Fiili durum üstünlügünden feragat edilmesi en doğru ifade olur ve diğer 14 adayı Yunanistan'a verir, kalan adalarda, Rodos'ta geniş bir muhtariyet uygulayacaktır. Bizim için önemli olan şu ifade yer alır antlaşmada, protokolde, mutabakatta: "Eğer" derler, "İngiltere Kıbrıs'1 Yunanistan'a devredecek olursa, İtalya da Rodos'ta plebisiti kabul edecektir".

Kıbris'a bakıyorsunuz, 1878'den 1914'e kadar egemenlik Osmanlı Devleti'nde, idare İngiltere'dedir. Kasım 1914'de, Birinci Dünya Savaşı'na 
Osmanlı Devleti'nin girmesinden bir hafta sonra İngiltere fiili ilhak uygulamıştır. Kıbrıs'ta ve zaten hem Sevr'de ve hem de Lozan'da İngiltere üzerindeki İngiliz egemenliği tanınmaktadır, öngörülmektedir. Ama gerek Ege adaları, gerek Kıbrıs bakımından önemli olan bir nokta, özellikle Lozan'ın 16'ıncı maddesinde nihai şeklini bulmuştur. Gerek Kıbrıs'ta, gerekse Ege adalarında gelecekte herhangi bir şekilde egemenliğe yönelik bir tasarruf söz konusu olursa, mesela Türkiye Cumhuriyeti Devleti bu haklarından feragat etmiş değildir. Yani buraların istikbaline, geleceğine yönelik herhangi bir şey söz konusu olursa, Türkiye Cumhuriyeti Devleti birinci öncelikli taraf olarak masa başında yer alacaktır. Tabii bundan önce Sevr'de böyle bir hüküm yoktur. Sevr'de Ege adaları için de böyle bir hüküm yoktur, Kıbrıs için de yoktur. Onun için "Eğer İngiltere Kıbrıs'ı Yunanistan'a terk edecek olursa, devredecek olursa, 14 aday 1 Yunanistan'a veren İtalya Rodos'ta da bir plebisit uygulamayı kabul eder" şeklinde bir hüküm yer almaktadır.

Venizolos bu mutabakatı Sevr Antlaşması'nın yürürlüğe girmesi şartına bağlandığından, Sevr Antlaşması da hiçbir zaman yürürlüğe girmediğinden, ölü doğmuş bir antlaşma olduğundan bu mutabakat da yürürlüğe girmemiştir. Ancak özellikle bugünün bazı meselelerine 1şık tutacak önemli bir belge olarak değerlendiriyorum.

Diğer taraftan Hocam, tabii karasuları konusunda kısa sürede, karasuları konusunu sizlere sunmaya çalıştı ama Lozan Barış Antlaşması ile ben Sevr' in bir mukayesesini yapmak istiyorum.

Sevr Antlaşması'nda, Osmanlı Devleti Anadolu'nun üç mili içerisinde hapsediliyor. Zaten batıdaki adaların egemenliği devredilmişti. Kuzeyde Yunan işgali altında olan 11 ada ve güneyde İtalyan işgali altında olan adalar, ismen sayılan 13 ve tabii adacıkları İtalya ve kuzeydekiler de Yunanistan'a devredilmişti. Gökçeada ve Bozcaada dahil, bunlar da Yunanistan'a devrediliyordu ve Türkiye ana kıtasının üç mili içerisine hapsediliyordu. Bunlardan daha da önemlisi, Osmanlı Devleti'nin bu hattın batısındaki her türlü hakkından feragat etmesi öngörülüyordu. Lozan ile temin ettiğimiz en önemli kazanım böyle bir feragatin söz konusu olmamasıdır. Her ne kadar 16'ıncı madde ilk okunduğunda bu anlama gelecek bir yorumlamaya da insanı yönlendiriyorsa da, bu maddenin oluşum aşamasına baktığınız zaman, yani bu maddenin ilk tabanını oluşturan Sevr'in 132. maddesi ve Lozan Müzakereleri'nde heyetimizin önüne konulan birinci taslak, bunlarla birlikte ve yapılan tartışmalar çerçevesinde incelediğiniz zaman Lozan'da böyle bir feragat söz konusu değildir.

Ama yine de Sevr yapıldığı zaman Ege Denizi'nde karasularının üç mil genişlikte olması anlayışıyla hareket edildiğini görüyoruz. Yani Sevr'e göre Türkiye ve Yunanistan ana kıtaları ve Ege Denizi'ndeki bütün adaların karasuları dışında kalan Ege açık deniz kesimi yaklaşık Ege'nin yüzde 75'ini oluşturuyordu. Lozan'da da karasularının üç mil genişlikte olması 
anlayışıyla hareket edildiğini görüyoruz. Yani Lozan'da da Ege'nin açık deniz kesimi Ege'nin yüzde 75'ini oluşturuyordu.

Hocam bahsetti; Yunanistan 1936'da karasularını alt1 mile genişletmekle, yüzde $75^{\prime}$ 'lik pastanın yüzde $25^{\prime}$ 'ini egemenliğine almış oldu. En azından alma iradesini ortaya koydu, 1964 yılında da bu fiili durumu biz de kabul etmiş olduk. Ama yüzde 25 gitti, yani Ege'nin yüzde 25 'i çok önemli yerden gitti.

Lozan Antlaşması şartlarına göre iki ulaştırma koridoru mevcut; batı su yolu ve doğu su yolu. Her ikisi de açık deniz rejimine tâbiydi. Altı mile genişletince batı su yolu kapanmış oldu ve burası Yunan karasularına dâhil olmuş oldu ve Yunan ülkesinin ayrılmaz bir parçası haline geldi.

Şimdi Yunanistan karasularını altı milin üzerine genişletme arzusu var. Açıç̧a bunu beyan ediyor ve diyor ki: "Ulusal stratejim çerçevesinde uygun bir zamanda ben karasularımı 12 mile genişleteceğim". Bu ne anlama geliyor? Hocam gösterdi... Bu şu anlama geliyor:

$\mathrm{Bu}$ egemenlik konusunu da bir tarafa bırakın, karasularını 12 mile genişletme arzusunda olan Yunanistan sizin egemenlik tezinizi zaten tartışma konusu bile yapmak istemiyor ve bütün Ege Denizi, belirli bölgeler hariç, bir Yunan gölü haline dönüşüyor. Bu durumda Türkiye'nin kuzeyi ile güneyi arasında ülkesel bütünlüğü bozuluyor.

Bugün Yunanistan Kardak kayalıklarını dahi tartışma konusu yapmak istemiyor. Yunan basını bizim yazılı ve görsel basından çok daha yoğun bir şekilde bu meseleleri irdeliyor, bizleri tartışıyor. Bazen çok olumlu eleştiriler de alıyoruz. İçeride almadığımız eleştirileri Yunan basınından alıyoruz.

Son dönemlerde şu tezi işliyorlar: "Hiçbir şekilde biz Uluslararası Adalet Divanı'na gitmeyelim. Ë̆er Adalet Divanı'na gidersek bu Türkler 150 adadan bahsediyorlar, divan bunların bir bölümünü bunlara verir ki biz buna tahammül edemeyiz".

Yani egemenlik meselesine de böyle bir bakışları var. Yani neticede Ege'yi bir Yunan gölü haline dönüştürme, kendisine egemenliği devredilmeyen bütün ada, adacık ve kayalıklara sahip olma ve Türkiye'yi Anadolu'nun üç mili içerisinde hapsetme arzusu var. Geriye ne kalıyor? Geriye Gökçeada ve Bozcaada kalıyor. Yunanistan'ın Gökçeada ve Bozcaada'ya yönelik çok ciddi çalışmaları var. Yunanistan'ın yetkilileri geliyor ve Gökçeada'da; "Kesinlikle arazi, mal, mülk satmayın. Satın alın, sizi destekliyoruz..." diyorlar.

Çok yoğun bir göç var. Yaz aylarında $30-40$ bin kişi geliyor. Gelsinler, biz memnun oluruz, ama tabii uluslararası politika, uzun vadeli politika, uluslararası strateji, bilen, bu ilmi yapanların bu işe bakışları biraz farklı olur. Çünkü aynı Yunanistan şahsen benim tespitlerime göre, özellikle 
Osmanlı arşivlerinde batı Anadolu'ya yönelik çok yoğun bir çalışma içerisinde ve Türk bilim adamlarını kullanıyor. Biz bilim adamlarımıza başvurup; "Ya şu konuda bir çalışma yapıyoruz, bir makale de siz yazar mısınız?"diyorlar. "Ne vereceksiniz?" diye sorulduğunda; "Bizim bütçemiz yok, biz size işte 500 lira, 1000 lira veririz" diye cevap veriyorlar. Oysa İngilizler 15 bin, 20 bin dolar veriyorlar gibi görünüyor, ama onu yazdıranın İngiliz değil, Yunanlı olduğunu biliyoruz.

Neticede çok yoğun bir şekilde batı Anadolu'ya yönelik de çalışmaları var. Yani o ödevini yapıyor, vazifesini yapıyor. Bize bu vazifeden ders almak geriye kalıyor.

Yine Yunanistan İstanbul-Atina hattının uçuş bölgesinin batısında kalan bütün Ege Denizi'ni egemenlik alanı olarak görmek istiyor. Hâlbuki İstanbul-Atina hattı, Bozcaada'nın güneyinden Anadolu'nun 22 milinden, Karaburun'da iki milden geçiyor, başka yerlerde ise 18 milden geçiyor. Bütün buların uluslararası hukukta kabul edilebilirliği yoktur.

Yani özetle şunu son cümle olarak sizinle paylaşmak isterim. Bir matematiksel yaklaşım içerisinde bugün Ege'de fiilen gerçekleştirilmiş bulunan ve hukukileştirilmek istenen rejim, yüzde 90 oranında Sevr'in öngördüğü rejimdir. Yani Ege'de bugün Sevr, Yunan fiili uygulamalarına ve bizdeki kabullenmelere baktığınız zaman yüzde 90 oranında gerçekleşmiştir. Bu noktaya özellikle Türkiye'nin Avrupa Birliği süreci içerisindeki konumu çerçevesinde özenle bakılmasının faydalı olacağını ben değerlendiriyorum.

PROF. DR. YAVUZ ERCAN (OTURUM BAŞKANI): Teşekkür ederim Sayın Kurumahmut. Evet, ikinci konuşmacımız Sayın Prof. Dr. Sertaç Başeren. Buyurun Sayın Başeren.

PROF. DR. SERTAÇ BAŞEREN: Teşekkür ederim, sayın başkan. Şimdi biraz önce arkadaşımı dinlerken haritada üzerinde bir hususu vurgulama ihtiyacı duydum. Ben ilk konuşmama şöyle başlamıştım:

“Ege uyuşmazlıkları aslında bir karasuları uyuşmazlığıdır. Ege uyuşmazlıklarının adını 'Ege karasuları uyuşmazlığı' koyabilmek mümkündür" diye başlamıştım. Burada, bu tabloda, bu diyagramdaki iki haritada da şu pembe gösterilen yerler egemenliği devredilmemiş ada, adacık ve kayalıklar. Yunanistan tabii ki bunların da hepsinin kendisine ait olduğunu savunmaktadır. Bunların tartışmalı olduğunu değil, bunların tamamıyla Yunan egemenliğinde olduğunu söylemektedir. Buna baktığınız zaman, işte şu pembeleri de sarıya boyarsanız asıl tablo o şekliyle ortaya çıkıyor. Yani şu pembeler bize bir soluk aldırma alanıdır. Böyle bakınca şöyle bir değerlendirme yapabilmek de mümkün:

Biliyorsunuz Kardak kayalıkları krizi sebebiyle iki devlet savaşın eşiğine gelmişti. Ama bence bu yeni bir savaş tehlikesi değildi, daha önce karasularının 12 mile çıkartılmasının bir savaş sebebi sayılarak önlendiğini 
söylemiştim. İşte Kardak kayalıkları sebebiyle yaşanan savaş tehlikesi aslında karasuları uyuşmazlığı sebebiyle ortaya çıkan savaş tehlikesinin bir yayılmasından ibaretti.

Aynı mevzuu hava uyuşmazlıkları bakımından da düşünebilmek mümkündür. Çünkü hava uyuşmazlıkları da karasularını uyuşmazlığına indirgenebilir. Konuşmama başlarken Yunanistan'ın 5017 sayılı ve 1931 sayılı Sivil Havacılık Yasası'ndan söz etmiştin. Bu Sivil Havacılık Yasası'nın, düzenlemelerini esas alarak Yunanistan bir Kraliyet kararnamesi çıkarttı, 18 Eylül 1931 tarihli bir Kraliyet kararnamesi. Bu Kararnameyle karasularının genişliğini hava polisliği maksadıyla 10 mil olarak ilan etti. Aslında 10 mile çıkarttığı karasularının genişliği, diyor ki: "Benim karasularımın genişliği 10 mil ama ben karasularında egemenlik yetkilerini kullanmayacağım. Karasuları devletin, ülkesinin bir parçasıdır, üzerindeki hava sahası da öyledir. Denizdeki egemenliği uygulamayacağım, ama buna karşılık hava sahasında, 10 millik hava sahasında egemenim" diyor.

$\mathrm{Bu}$ da karasuları uyuşmazlığının içerisinde yer alan bir konudur. Yunanistan karasularını 12 mile çıkartacak olursa, karasuları ile hava sahası genişliği arasındaki fark da ortadan kalkacaktır. Sonuçta olay Türkiye aleyhine ve Yunanistan'ın genişlettiği hava sahası lehine çözülecektir.

10 mil hava sahası konusu, belki de Yunanistan'ın çok zayıf olduğu noktalardan birisidir. Bir an aklıma, 'en zayıf olduğu nokta' demek geldi ama, silahsızlandırılmış adalar hiçbir şekilde göz ardı edilemeyecek bir konudur. Bu yüzden bunu ikinci planda görmekte yarar var.

Açık denizin üzerinin uluslararası hava sahası olması icap eder. Buralar uluslararası yetkiye tabii olan alanlardır. Yunanistan'ın karasularını 10 mile çıkartıp deniz alanında bu yetkiyi uygulamayarak ortaya çıkarttı̆̆ı durum bu hükümle bağdaşmaz. Burada belki bir çeşit hukuka karşı hileden bile söz edilebilir. Yeryüzünde başka hiçbir devletin herhangi bir uygulamasında ve düzenlemesinde böyle bir durum yoktur. Doğrusunu isterseniz $10 \mathrm{mil}$ genişliğinde hava sahası iddiasına itiraz eden sadece Türkiye değildir. Başka devletler de bu konuya itiraz etmektedirler. Mesela Amerika Birleşik Devletleri 10 millik hava sahasını kabul etmemektedir.

10 Millik hava sahası ile ilgili Yunanistan'ın savunması sadece bir tek noktada toplanabiliyor. Diyor ki: "Ben bu işi 1931 Yasası'na dayandırarak, 1931 Kraliyet Kararnamesi ile ilan ettim, 1931'den bu yana itiraz etmediniz". Ayrıca Türkiye'ye "Bu mevzu ilk defa 1974 yılında bir tatbikat sebebiyle ortaya çıkmıştır. 1931'den 1974'e kadar, 1975'e kadar Türkiye buna itiraz etmeyerek zımni olarak tanımıştır, kabul etmiştir" diyor. Bu doğru değil. Öncelikle şunu söylemekte yarar var: Bu konuyu Yunanistan 1931 Kraliyet Kararnamesi ile kabul etmiş olabilir, ama bunun uluslararası alana yansıması o söylediğim tatbikat sebebiyle ve 1974-1975'de Yunanistan'ın ilan ettiği NOTAM'da yer almıştır. Dolayısıyla uluslararası 
platforma intikalinin hemen arkasından Türkiye de itiraz etmiştir. Burada böyle bir gecikme söz konusu değildir.

Yunanistan'ın hava sahası uyuşamazlıkları içerisinde, yarattı̆̆ı uyuşmazlıklar içerisinde en önemlilerinden bir tanesi de FIR uyuşmazlığıdır. FIR uçuş bilgi bölgeleri anlamına gelmektedir ve sivil havacılığa, uçuş ile ilgili hizmetlerinin sunulduğu bir alandan ibarettir. FIR'a ilişkin uyuşmazlıklardan ilki FIR'ın sınırına ilişkin uyuşamazlıktır. FIR'n sınırı 1952 tarihli bir haritada da belirlenmiş, ama bu Yunanistan'ın iddia ettiği gibi bir egemenlik sınırı değildir. Egemenlik sınırı olmadığını gösteren önemli delillerden bir tanesini arkadaşım söyledi, ben de onu tekrar edeyim. Şurada, hemen Karaburun civarında FIR Türkiye'ye iki mil kadar yaklaşmaktadır. Yani Türkiye'nin karasuları içerisinden geçmektedir. Böyle bir sınırın siyasi sınır olabilmesi mümkün değildir. Kaldı ki, teorik olarak da zaten, hukuk teorisi açısından da baktığınızda bunun egemenlik sınırıyla yakından, uzaktan bir ilişkisi yoktur. Ama Yunanistan'ın temel arzusu, bunu bir siyasi sınır ve bütün FIR alanını da Yunanistan'ın egemenlik sahası olarak görmektir. Hiç abartmıyorum, bakın Yunanistan'ın eski Milli Savunma Bakanlarından birisi olan Cohacopoulos'un resmi beyanları var. Bu beyanlar dergilerde yayınland. Cohacopoulos o dönemlerde diyor ki:

"İki yıl içerisinde bütün FIR sahasını uçaksavar füzeleriyle kontrol altına alacağız!” Buyurun... Bütün FIR alanını kendi egemenlik sahası olarak görmektedir. Bunun uluslararası hukukla uzaktan yakından bir ilişkisi yoktur.

FIR ile ilgili uyuşmazlıklar sadece FIR'ın sınırıyla, FIR'da kullanılan yetkilerin niteliğiyle ilgili değil, başka konularda da problemler bulunmaktadır. Chicago Sözleşmesi sadece sivil uçakları kapsamakta, askeri uçakları kapsam dışı bırakmaktadır. Buna karşılık Yunanistan bu düzenlemeleri askeri uçaklar bakımından da uygulamaya çalışmaktadır. Bu başlı başına hukuka aykırı bir durumdur.

Bir başka mesele NOTAM'larla ilgili meseledir. FIR hizmetlerinin Yunanistan'a verilmiş olması sebebiyle bu FIR alanı içerisinde NOTAM'ları yayınlama yetkisi de ona verilmiştir. Türkiye NOTAM'a dayanan bir faaliyet yapacak olursa veyahut NOTAM ilan etmesi icap edecek olursa, bunu belirli bir süre önce Yunanistan'a bildirmek ve Yunanistan da bu NOTAM'ları ilan etmek durumundadır. Oysa Yunanistan Türkiye'nin bildirdiği NOTAM'ları ya değiştirerek yayınlamakta veyahut da geç yayınlamaktadır. Bu da uluslararası hukuka aykırı bir şeydir ve tamamen Yunanistan'ın Ege'yi FIR esasında sahiplenme iddialarını ortaya koymaktadır.

Burayı egemenlik alanı olarak gördüğü için tabii uygulamaları da hep bu paralelde olmaktadır. Ege açık denizi üzerinde uçan Türk uçaklarından, Türk askeri uçaklarından uçuş planı istemektedir. Bunların verilmesi 
gerekmez. Uluslararası hukuka göre bunları talep etme yetkisi yoktur, ama Yunanistan bu talepleri sürekli olarak Türkiye'nin önüne koymaktadır.

Bir başka sorun kontrollü hava sahaları ile ilgilidir. Yunanistan FIR'1 egemenlik alanı olarak görüyor ve iddia ediyor. Bu iddiasını realize etmek için de kontrollü hava sahalarından istifade etmeye çalışıyor. Limni'de bir terminal kontrol alanı ilan etmişti. Bu üç bin deniz mili karelik bir alanı kapsıyordu. Şurada, Limni Adası'nın etrafında üç bin deniz mili karelik bir alanın olması dehşet verici bir şeydir! Bunu yapmakla aslında bölgeyi uçuşa kapatiyordu. Sonra bunu 1300'e kadar indirdi, ama hâlâ bu bile çok büyüktür.

Diğer bir mesele için de şu harita üzerinde konuşalım... Bakın şu haritayı esas alırsak Türkiye'nin savaş uçaklarının Ege açık denizlerine çıkış alanlarının çok sınırlı olduğu görülmektedir. Zaten şu güneyi düşünün, şu pembelerin de (Egemenliği andlaşmalarla Yunanistan'a devredilmemiş adalar ve karasularının da) iddia edildiği gibi Yunanistan'a ait olduğunu düşünecek olursanız şurada (Menteşe Adaları Bölgesinde) açık denize çıkış yok. Bu sadece 12 milde ortaya çıkan bir durum değil, altı milde de durum aynıdır. Şurası kapalı, şu pembeler yanıltmasın. Pembeler tartışmalı alanlar, Yunanistan bunların da kendisine ait olduğunu söylüyor. Buralardan çıkış yok. Nereden çıkış var? İşte şuralardan (genel olarak Anadolu'nun Kuzey Ege sahillerine işaret edilerek) biraz çıkış var, biraz şuradan çıkış var, biraz da şuradan var. Türk uçaklarının açık denize başka çıkış alanları yok. Yunanistan Ege Denizi'ni sahiplenme arzusu içerisinde olduğu için bu çıkış alanlarını da elimizden almaya çalışmaktadır. Bunun için de tam bu çıkış alanlarının önünden Kuzey-Güney istikametinde hava koridorları ilan etmektedir. İlan edilen hava koridorları tabii ki Türkiye'nin açık denize çıkışını şu anlamda engelliyor: Türkiye'ye her çıkışında bu konularla ilgili uyarılar yapacaktır ve sivil hava koridorlarındaki trafik aksayacaktır. İşte bunu temin ederek Ege'ye her çıkışında, Ege açık denizine her çıkışında uluslararası sivil havacılıkla ile Türkiye'yi karşı karşıya getirme çabası içerisindedir. Bu da hukuka aykırıdır. Koridorların tesis edilebilmesi için bölge devletleri arasında uzlaşı gereklidir. Bu uzlaşı mevzu ICAO'nun yetkili organları tarafından da onaylanacak ve uluslararası antlaşma haline getirilecektir. Daha sonra da sivil ulaşım koridorları ilan edilecektir.

Geçmişte bu sıkıntıları çok yaşayan Türkiye, bunların uluslararası hukukla bağdaşmadığına ilişkin Uluslararası Sivil Havacılık Örgütü'nün Konseyi'nden kararlar da çıkarttı. Uzun süre Yunanistan bu işe direndi ve en son J-60 ile ilgili kararı bundan bir buçuk sene önce yahut iki sene önce uygulamaya koydu, bu sorun da bir çözüm bulmuş oldu.

Yunanistan'ın bu yaklaşımlarına karşı Türkiye'nin tezleri nelerdir? Onları hemen söyleyelim. Bir tanesini zaten söylemiştim. Diyor ki: "10 mil hava sahasına 1931 'den 1974'e kadar itiraz etmedin", cevabımız da şöyle: 
"Bunun uluslararası hukuka yansıması, uluslararası platformlara yansıması 1974-1975 yıllarına düşer, biz de hemen o yıllarda buna itiraz ettik" diyoruz.

Yunanistan'ın uluslararası hukuka aykırı olarak uçuş planları talep etmesine karşılık askeri uçakların Sivil Havacılık Sözleşmesi'ne tabii olmadıklarını söylüyoruz ve uçuş planı vermiyoruz.

Bir de tabii FIR ile ilgili kritik bir konu var. Yunanistan FIR'1 bizim aleyhimize suiistimal etmektedir. Aslında bu konu eskiden hiç böyle düşünülmezdi, tamamıyla Yunanistan'ın suiistimaliyle ortaya çıkan bir durumdur. 1950'li yıllarda, biliyor musunuz, Sivil Havacılık Örgütü Yunanistan'ın tamamının FIR hizmetlerini Türkiye'ye teklif etmişti. O kadar büyüktü ki teklif edilen alan, bugünkü Yunanistan'ın tamamını ve hatta Arnavutluk'u da içine alıyordu. Biz bu teklifi değerlendiremedik. Ama bunda o yıllar için çok sürpriz bir şey yok. Türkiye'nin böyle Ege'yi sahiplenmek, Yunanistan üzerinde bir kontrol kurmak gibi bir arzusu yoktu. Bu normal bir şey de değildir. Bu Yunanistan'ın ortaya koyduğu bir anlaşılmaz tavırdır. Yunan siyaseti açısından anlaşılır tavır olmasına karşın Uluslararası Hukuk bakımından anlaşılmaz bir tavırdır. O dönemde bu hizmetleri vermek bir masrafa bali olduğu için devletler bu işten kaçınırlardı. $\mathrm{Bu}$ genel tutuma paralel olarak Türkiye de bu hizmetleri sunmak istememiştir. Sonra 1952'de bugünkü FIR'ın esasını oluşturan andlaşmalar imzalanmış ve 1958'de de küçük bir düzeltme yapılmıştır. Yunanistan'ın suiistimalleri karşısında FIR'ın yeniden belirlenmesi, batıya kaydırılması konusu akla gelebilir. Fakat bu fikri uygulamaya koymak kolay bir iş değildir. Karşılıklı bölge devletlerinin buna onay vermesi gerekir. Bu cephesiyle zor bir iştir.

Son bir konuyu Ege mevzuu ile ilgili konuşayım. Bu güvenlik meselesidir. Şimdi şu haritaya bakın. Şuradan kalkan bir uçak veyahut da Yunanistan'dan kalıp, anakaradan Türkiye'ye doğru yaklaşan bir uçak düşünün, bu uçak Midilli Adası'na mı inecek, Türkiye'nin içerisine girip taarruz mu edecek? Buralarda (özellikle Limni Adasını işaret ederek) askeri havaalanları var. Olmaması gerekiyor, ama var. Bu Türkiye açısında bir güvenlik mevzudur. Şu mesafeyi jet uçaklarının herhalde alması birkaç dakikalık bir iştir. Türkiye'nin bir güvenlik alanına ihtiyacı vardır. 714 sayılı NOTAM bunu temin etmişti. Ama biz maalesef 714 sayılı NOTAM'1 kaldırdık. 714 sayılı NOTAM aslında ilk defa Türkiye'nin uygulamaya soktuğu bir durum da değildir. Uluslararası hukuk kuralları içerisinde izah edilebilirliği de vardı ve hatta bazı devletler 714 sayılı NOTAM'a riayet etmeye başlamışlardı. Ama biz 714 sayılı NOTAM'ı o günün koşulları içerisinde kaldırdık. Bu güvenlik sorunu ile ilgili olarak Türkiye ve Yunanistan arasında çok konuşmalar ve görüşmeler oldu. Onlar da şunu söylüyorlar: 
"Şuradan, Anadolu kıtasından, kıta üzerinden bir uçak geliyor, acaba adalara mı yüklenecek, yoksa adaların arasından denize mi geçecek? Bu da bizim için güvenlik sorunu" diyorlar. Ve tartışmalar şuna dönüşüyor: İşte; "Biz şu Ege Denizi'nin belirli bir mesafesinden Anadolu'ya yaklaşan uçakların kimliklerini bildirelim, ama siz de Anadolu kıtası üzerinden adalara yaklaşan uçakların kimliklerini bildirin" diyorlar. Ancak ikisi arasında fark var. Bir tanesi açık deniz üzerinde gelen bir uçak, öbürü Anadolu kıtası üzerinde uçan bir uçaktır. Kendi topraklarımızın üzerinde uçan bir uçă̆ın gideceği yeri, kimliği, istikametini bildirmemizi istediler. Bu kabul edilebilir, doğru bir yaklaşım değildir. Ama öbür taraftan, Türkiye'nin açısından konuyu düşünecek olursanız, açık denizin üzerinden, şuradan kalktığını takip etmediniz, görmediniz, açık deniz üzerinde uçan bir uçağı tespit ettiniz, geliyor, Anadolu kıtasına doğru yaklaşıyor... Dakikalardan bahsediyoruz. Midilli'ye mi inecek, yoksa Anadolu kıtasına mı geçecek? Nereden bileceksiniz? Bu sorunun cevabi yoktur. Bu sorunun cevab1 Türkiye'deki, Türkiye'nin Ege konusundaki güvenlik sorunudur ve görüşmeler bu konuda sonuçsuz kalmıştır. Bu sorun hâlâ devam etmektedir.

İlginiz için teşekkür ederim.

PROF. DR. YAVUZ ERCAN (OTURUM BAŞKANI): Ben de size teşekkür ediyorum Sayın Başeren. İkinci oturumun son konuşmacısı, panelin de son konuşmacısı Sayın Prof. Dr. Hüseyin Pazarcı. Buyurun Sayın Pazarc1.

PROF. DR. HÜSEYIN PAZARCI : Teşekkürler Sayın Başkan.

Ben arkadaşlarımın ve bir kısmını da benim sunduğum Ege sorunlarının çözüm yolları üzerindeki arayışlardan söz edeceğim. Ayrıca bu sorunlar ortaya çıkmaya başladığından bu güne kadar ne gibi girişimlerde bulunulduğu, iki tarafın yaptıkları, önerdikleri girişimler, bunların sonucu üzerinde bazı şeyler söylemek istiyorum. Sonra olayı günümüze kadar getirmek, çok kısaca da sonuç itibarıyla bundan sonra ne olabileceğine kendi düşüncelerim çerçevesinde dikkatinizi çekmek istiyorum.

Ege sorunları 1970'li yılların başlarında çıktı, 1973-1974 yılları içinde ortaya çıktı, ama olayların kaynağı, menşei daha eskilere tabii uzanıyor. Fakat " 1974 'te nasıl çıktı?" diye baktığımızda, ilk önce kıta sahanlı̆̆ üzerinde Yunanistan'ın daha önce kendi karasuları üzerinde verdiği petrol araştırma iznini Taşoz Adası civarında, kuzeyde bu kez Off Shore petrol aramaya, yani açık denizde petrol aramaya doğru yöneltmesi ve "Burası benim kıta sahanlığımdır" demesi üzerine olaylar çıktı. Bunun üzerine Türkiye tarafından; "Hayır, bu açık denizde sen araştırma yapamazsın, benim kıta sahanlığıma tecavüz etmen söz konusu olabilecektir" denildi. Türkiye bazı karşıt önlemler aldı ve iş 1974 yılı başlarında 1sınmaya başladı. Ama ardından 1974 yazında Kıbrıs olayı geldi. İște bu Kıbrıs olayı, kıta sahanlığının bu durumu ve 1960'lı yılların sonunda, 1969'dan itibaren bizim 
protesto etmeye başladığımız doğu Ege adalarının askerleştirilmesi sorunu gibi olaylar karşısında ve Sayın Başeren'in sözünü ettiği adaların üzerinde, Yunanistan'ın büyük güvenlik bölgeleri oluşturmasına sebep oldu. Yunanistan'ın özellikle Midili üzerinde son derece geniş koruma ve güvenlik bölgeleri oluşturması olayların artık ortaya dökülmesine yol açtı. 1974 yılında, iki devlet arasında sorun olduğu üzerinde biz Türkiye olarak bir hayli bilinçli hale geldik. Türkiye, daha önce yavaş yavaş dantele gibi Yunanistan'ın böyle örüp, kendisi lehine yarattığı oldu bittilerin çok daha bilinçli bir şekilde, farkına varmış oldu ve buna izin verilmeyeceğini ifade eder hale geldi. Dolayısıyla Ege sorunları 1974'ten itibaren, Kibris'ın da tabii Yunanlılarda yarattığı o psikolojik etkiyle kristalize oldu ve ortaya çıkmış oldu.

Sorunlar çıkınca tabii çözüm aranması söz konusu olacaktır. Çözüm aranması konusuna girilince -işin özü itibarıyla söylüyorum- en başından itibaren Yunanistan "Bir tek kıta sahanlığı sınırlandırması sorunu söz konusudur. Bu aramızda gerçek uyuşmazlıktır. Sizin iddianızla bizim karşıt iddialarımız var. Ama onun dışında diğerleri bizim egemenlik sorunumuzdur. Uluslararası hukukun bize tanıdığı ve güvenlik önlemleri, koruma önlemleri sorunudur ve dolayısıyla biz bunların konuşulması taraftarı değiliz" demeye başlamıştır.

Ama buna rağmen Türkiye-Yunanistan arasında heyetler halindeki ilk görüşmeler 1975 Mayıs'ında başlamıştır. İki NATO üyesi devlet olmamız hesabıyla da NATO devletleri de; "Anlaşın! Böyle bir ayrılık yaratılmasın" şeklinde baskılar yapmaya başlamışlardır ve -o dönemdeki- "Sovyetler'in pozisyonunu güçlendiriyorsunuz" denilmiştir. Sonuçta doğal olarak zaten bir çözüm arayışına başlanmıştır.

İlk görüşmelerde hava sahası sorunları ve kıta sahanlığı üzerinde konuşulmuştur. Biz de ayrıca doğu Ege adalarının askerden arındırılması sorununu ileri sürmüşüzdür. Sonuç itibarıyla ilk baştaki görüşmelerdeki yaklaşım ve anlayış en başta sorunların neler olduğunu belirlemek ve saptamak üzerine kurulmuştur. Ama ikinci yanı; "Bu sorunlara hangi yolla çözüm bulacağız?" konusu olmuştur ve bunlar ikisi birlikte, esasa ilişkin olanlarla çözüm yolları üzerinde birlikte ele alınır olmaya başlanmıştır. O çözüm yolları üzerinde ise Yunanistan şunu ifade etmiştir:

“Tek sorun olan kıta sahanlığı konusunu Uluslararası Adalet Divanı'na götürelim.Diğerleri bizim aramızda sorun değildir. Onlar benim ulusal egemenlik haklarımı kullanmamdır" demiştir.

İşte bunun üzerine Türkiye ise "Bir kere nelerin sorun olduğunu tek taraflı olarak sen belirleyemezsin. Eğer karşıt iki iddia varsa, hukukta bu bir uyuşmazlık oluşturur ve o zaman bunu çözmemiz gerekir. Ayrıca bu tür sorunlarda işin o kadar çok birbirleriyle bağlantılı ve karmaşık yanları var ki, iş her haliyle görüşmelerle başlar ve sonuçlanır. Bizim arzumuz işin 
karmaşıklığı nedeniyle bunların görüşmelerle de sonuçlandırılmasıdır. Olabildiğince görüşmeler yapmak suretiyle en doğruyu, en makulü birlikte bulalım” şeklinde bir yaklaşım sergilenmiştir.

Daha sonra Mayıs 1975 'de, Brüksel'de NATO toplantısı olmuş ve başbakanlar bu kez görüşmüşlerdir. O dönem Demirel ve Karamanlis, başbakanlar. Oradan "sorunları barışçı çözüm yolları çerçevesinde çözelim" diye bir ortak bildiri de çıkmıştır. Bu ortak bildiride bizim tarafımızdan bir hata yapılmıştır. Ortak bildiride "Kıta sahanlığı sorunu Uluslararası Adalet Divanı'na götürülür”" mealinde bir söz vardır. İşte bunu zamanla Yunanistan kullanmıştır ve kıta sahanlığı konusuyla ilgili olarak Uluslararası Adalet Divanı'na gitme üzerine daha fazla ısrarcı olmaya başlamıştır. Ancak Türkiye bunun hemen akabinde, bu ortak bildiriyle ilgili -tabii başbakanlar bizzat kendileri değil, uzmanlara bırakıyorlar anladığım kadarıyla- hemen şunu iddia etmiştir:

“Bu tek taraflı olarak Adalet Divanı'na gitme yetkisi verme anlamında değildir. Uluslararası Adalet Divanı'na gidilecekse birlikte gidilir ve bir tahkimname yapılır" diye hemen ardından bu hatasını düzeltme yoluna girmiş̧ir. Böyle bir konumda 1975'in sonlarına kadar gelinmiştir.

1976'da görüşmeler daha fazla, daha içerikli olsun diye Bern'de üç kez toplantılar yapılmıştır. Birisi 31 Ocak-02 Şubat tarihleri arasındadır. İkincisi 19-20 Haziran 1976 ve üçüncüsü de 02-11 Kasım 1976'dadır.

$\mathrm{Bu}$ toplantılarda hem öze ilişkin hem de çözüm yöntemine ilişkin arayışlara gidilmiştir. Ama ikinci Bern toplantısından sonra, üçüncüsünden önce Yunanistan; "Biz görüşme de yaptık işte, sonuçta bir yere varmamız söz konusu değil, zaten her şeyi görüşmeyi kabul etmiyorum" demek suretiyle sadece kıta sahanlığı sorununu Uluslararası Adalet Divanı önüne tek taraflı bir başvuruyla, yani tahkimname ile değil, tek taraflı bir başvuruyla 10 Ağustos 1976 'da götürmüştür.

$\mathrm{Bu}$ dönemde bir yandan tekrar Bern görüşmesi yapılırken, buna paralel olarak Kasım'da, Adalet Divanı da konuya bakmaya başlamıștır. Yunanistan Adalet Divanı'ndan iki şey istemiştir. Öncelikle “Koruyucu önlem al!", yani ihtiyati tedbir dediğimiz "önlem kararı al!" demiştir. Yunanistan'ın başvuru nedeni Türkiye'nin açık denizlerde sismik araştırmalar yapması olarak gösterilmiştir. "Benim kıta sahanlığımda sismik -yani sesle ve titreşimlearaştırma yapıyor. Bu konuda ben zarar görüyorum, bunu engelle!" demiştir.

İkinci olarak da; "Divan olarak yetkilisin, bu konunun özüne ilişkin olarak kıta sahanlığı sinırlandırmasında ilkeleri bize bildir ve bu konunun çözümünü sağlayalım" demiştir. Ama kendisinin iddiası, sınırın orta çizgi olduğu, eşit uzaklık çizgisi olduğu şeklindedir. Kıta sahanlığı sınırlandırmasının, kendisine ait olan adalarla Türkiye arasında olmasını istemiş̧ir. Böylece Yunanistan eşit uzaklık ilkesine göre Türkiye'ye çok büyük öçlüde ïç mil civarlarında bir alan bırakan, yani bugünkü aşağı- 
yukarı karasularımızın dahi berisinde kalabilecek nitelikte bir kıta sahanlığı sınırlandırması yapılmasını istemiştir.

Divan koruyucu önleme gerek olmadığını söylemiştir. Çünkü sismik araştırmayla onarılmaz bir zarar verme söz konusu değildir. "Herhangi bir zarara uğramaman dolayısıyla böyle bir yetkiyi kullanmayacağım” demiştir.

İkinci olarak da Divan yetkisi konusunda da, Yunanistan'ın ileri sürdüğü Divan'ın yetkili olduğu tezlerini ret etmiştir. Bunların bir tanesi 1928'de yapılan uyuşmazlıkları barışçı çözüm konusundaki Cenevre Sözleşmesi'dir. Bu sözleşmeye göre taraflar aralarında, altı ay içinde başka yollarla halledemedikleri uyuşmazlıkları tek yanlı olarak Divana götürebilecektir.

Ama Yunanistan bu sözleşmeyi onaylarken o tarihte bir de çekince belirtmiş ve demiş ki: "Ülkesel sorunlar Divan'ın yetkisi dışındadır”. Divan bir kere sözleşme yürürlükte mi, değil mi? diye değerlendirmek durumunda olmasına rağmen her haliyle; "Bu çekince, eğer yargı yetkimi düşürürse sözleşmenin yürürlükte olup, olmadığına bakmam dahi gerekmemektedir" demiştir. Çekinceyi değerlendirdiğinde de; "Kıta sahanlığı kavramı ülkesel statüye ilişkin bir sorundur ve dolayısıyla ben o sözleşmeye dayanarak çekince koyduğu için Yunanistan- yetkili değilim" demiştir.

Onun dışında, sözünü ettiğim 1975 tarihli ortak bildirideki, kıta sahanlığı sınırlandırılmasının Divan'a götürülmesi konusunda Divan; “1975 Brüksel Bildirisi'nin unsurlarının tek başına Divan'a götürüleceği anlamına gelmez, zaten Türkiye, kontekstine baktığımızda işin, eninde ve sonunda bunun tek taraflı olamayacağını ifade etmiştir" demiştir ve orada kesmiştir.

Yetkisizlik kararı 1978'de sonuçlanmıştır. Divan 1976'da koruyucu önlemleri ret etmiş ve 1978'de ise "Yetkisizim" demiştir.

Bunun üzerine iki taraf; “Çözüm arayışlarını sürdürelim” şeklinde daha üst düzeyde arayışlara girmişlerdir ve 10-11 Mayıs 1978'de Montrö'de iki ülkenin başbakanı bir araya gelmiştir. "Uzman heyetler tekrar görüşsün" şeklindeki bir mutabakattan başka bir sonuca direkt varmaları söz konusu olmamıştır. Uzman heyetler sonra Aralık 1978 ve Şubat 1979'da ilki Paris'te ve sonraki Viyana'da olmak üzere buluşmuşlardır ve görüşmüşlerdir.

Ama dikkatinizi çekmek isterim. Yunanistan daha önce görüşmeler konusunda biraz ayak sürümeye başlamışken, Divan'a başvurduktan sonra aldığı olumsuz cevaptan etkilenmiş ve ikinci olarak da 1979 Martı'nda Yunanistan Avrupa Topluluklarına Katılma Andlaşması'nı imzalamıştır. Bu vesileyle Avrupa toplulukları Yunanistan'a o zaman demişlerdir ki, -ama öyle çok güçlü bir şekilde değil, bugün bize yaptıkları türden değildemişlerdir ki: "Bize sorun getirme. Ege sorununu çözerek gelmen uygun olacaktır". Bunun üzerine Yunanlılar, örneğin Viyana'daki toplantıya sanki işin özünün çözümüne girildi gibi izlenimler vermek için ellerinde büyük 
harita ve kartografik belgelerle gelmişlerdir. Bu yolla sanki sınır çiziyoruz izlenimi vermek istemişlerdir. Avrupa Topluluğu'na da "Biz sorunu çözme yolunda ilerleme kaydeder gibiyiz, haberiniz ola! Korkmayın, size sorun ithal etmeyeceğiz" mesajını vermişlerdir. Yani bu görüşmeler böyle tribünlere de oynanarak yapılan görüşmeler şeklinde geçmiştir..

$\mathrm{Bu}$ verilerden sonra Yunanistan Avrupa Birliği'ne de 1981'de girince, tam üye olunca, Türkiye'ye tam bir sırt çevirme durumuna girmiştir. $O$ dönemin başbakanı Andreas Papandreu - Yorgos Papandreu'nun babas11981'den itibaren Türkiye ile görüşmeleri kesmiştir. 1981'den 1995'e kadar zaman zaman iki taraf da sorunları kamuoyuna sunma durumuna girmiştir. Bazen da "it dalaşı" dediğimiz havada bir karşılaşma söz konusu olduysa, bilmem bir adacıkla, adayla ilgili bazı küçük sorunlar ortaya çıktıysa da, iki taraf da bunu kullanarak diğerini protesto etme yoluna girmiştir. 1995'e kadar bu iş böyle gelmiştir.

1995 'de konu tekrar alevlenmiştir. Çünkü 1995 'de Yunanistan "1982 Sözleşmesi” dediğimiz Deniz Hukuku Sözleşmesi'ni onaylamıştır ve onayladığında da -Sertaç Başeren arkadaşımızın da ifade ettiği gibi- kısa bir süre sonra Meclis'ten bir karar çıkartmıştır. Bu kararda " 12 mile kadar ben istediğim zaman, uygun gördüğüm anda karasuları ilanı hakkım var, bunu gerçekleştireceğim, bu hakkı mahfuz tutuyorum" demiştir. İşte Türkiye de, Türkiye Büyük Millet Meclisi'nde buna cevaben; "Bunu yapmaman gerekir, bu iki ülke arasında sonuç itibarıyla çatışmayı getirir" mealindeki kararı almıştır.

1995'in sonlarına doğru, tam 31 Aralık 1995'te, bu kez Kardak olayı patlamıştır. Bir Türk gemisinin Kardak kayalıklarına çarpmasıyla ve yetki kimde, hangi devlet müdahale edecek, kurtarma çalışmalarında ve başka yetki kullanılmasını gerektiren, yargı yetkisi ve saire gibi şeyler söz konusu olacaksa, bunun hangi devlete ait olacağı konusunda sorun çıkmıştır. Kardak olayının özellikle 1996'nın başlarında, son derece alevlendirici bir etkisi olmuştur. Deniz Hukuku Sözleşmesi'ne taraf olurken Yunanistan'ın karasularına olan yaklaşımı da yine sinirleri germe etkisi yapmıştır.

Bu olaylar üzerine, yine tabii uluslararası düzeyde istekler, baskılar ve taleplerle karşılaşan Türkiye, bir çözüm arayışı atağına geçmiştir. 24 Mart 1996'da Türkiye Başbakanı Mesut Yılmaz, yeni öneriler götürme yoluna girmiştir. Bu çerçevede yeni önerilerde; "İşin özüne ilişkin olarak sorunlara ilişkin yöntemleri birlikte araştıralım ve gerekirse üçüncü kişilerin müdahalesi dahil, yani arabulucu, dostça girişimci, uzlaştırmacı, hakem ya da Uluslararası Adalet Divanı gibi üçüncü kişilerin müdahalesi ve kararına da izin verecek şekilde bu yöntemleri araştıralım" demiştir.

Yunanistan buna sırt çevirmiştir, demiştir ki: "İlk önce sen Kardak'ı tek taraflı olarak Uluslararası Adalet Divanı'na götür. Çünkü bu benimle olan bir sorun değildir. Sen kendi kendine sorun yarattın, böyle bir olay yoktur, 
buralar benimdir, dolayısıyla sen istersen Divan'a git, o konuyu bir kendin bakımından açıklığa kavuştur, ama benim bakımımdan bu bir sorun değildir. Biz ikimizin birlikte götürebileceğimiz tek sorun sadece ve sadece kıta sahanlı̆̆ı sorunudur, o da Uluslararası Adalet Divanı'na götürülmesi gereken bir sorundur" demiştir. Dolayısıyla burada da bir yere gelinememiştir.

Yunanistan ile bu ikili düzeyde çözüm arayışları sürerken ilk başlarda Avrupa Birliği'nin de "Bana sorun getirme" nitelikli o zayıf mesajlarını biraz belki hesaba katarak Avrupa Birliği'ni pek devreye sokmamıştır. Ama 1997 yılına geldiğimizde Türkiye'nin de Avrupa Birliği'ne tam üyelik başvurusu bulunması konusu çerçevesinde Avrupa Birliği'ni daha fazla devreye sokan birtakım çalışmalar içine girmiştir. Yunanistan bu çerçevede 29 Nisan 1997'de Lüksembourg'da Avrupa Toplulukları-Türkiye Ortaklık Konseyi toplandığında Türkiye'ye bir akil adamlar toplantısı yapılması önerilmiştir. Türkiye bunu kabul ettikten sonra Yunanistan'a iletilmiş ve Yunanistan'da da kabul edilmiştir. Her devlet ikişer akil kişiyi atayacaklar, bunlar bir çözüm bulma denemesi içine gireceklerdir. Ancak bu süreç başlayamamıştır. Yunanistan yine; "İşin özü kıta sahanlığıdır, öbürlerine gerek yoktur!" dediği andan itibaren bizim akil adamlar da: "İşin başka yanları da vardır" dediğinden akil adamların toplanması söz konusu bile olamamıştır.

Daha sonra Amerika Birleşik Devletleri'nin taraflar üzerindeki etkisini kullanmasıyla 1997 yılı içinde ortaya çıkan bir Madrid Mutabakatı olayı vardır. Bunun tarihi 8 Temmuz 1997'dir. Bu Madrid Mutabakatı'nda özellikle, Amerika Birleşik Devletleri Dışişleri Bakanı Allbright Ege Sorunlarıyla ilgili olarak ikili ilişkilerin geliştirilmesi, barış, egemenlik ve yaşamsal çıkarlara saygı ve tek yanlı davranmama konusunda iki tarafın bir mutabakata varmalarını sağlamıştır. Türkiye ve Yunanistan barışçı çözüm yollarıyla bu işleri halletmeyi bu mutabakatla kabul etmişlerdir. Ama bunda da bazı ilkeler ifade edilmesine rağmen somut bir adım atılamamıştır. Böylece 1997 yılından itibaren Yunanistan Avrupa Birliği'ni giderek daha çok devreye sokmaya başlamıştır.

Avrupa Birliği 1997'de "Ajanda 2000" diye, "Gündem 2000" de diyebiliriz, bir belgeyi kabul etmiştir. Bu 1997'deki Ajanda 2000, 2000 yılına kadar başvuracak veya başvurmuş olan aday devletlere yönelik olarak şunu ifade etmektedir, 8'inci bölümünde: "Sınır uyuşmazlıklarınızı çözmeden AB'ye giremeyeceksiniz. Bu sınır uyuşmazlıklarınızı çözün” demiştir. Kastettikleri sorunlardan birisi Macaristan- Slovakya arasındaki akarsu üzerinde bir baraj yapma konusudur. Bu barajla ilgili olarak bir ülkesel ve sınır sorunudur. Litvanya ile Latvia arasında deniz sorunu vardır. Ama kafalarındaki esas sorun Ege sorunudur.

Ajanda 2000'nin 8'inci bölümünde Avrupa Birliği bu çerçevede: "Avrupa Birliği ile katılma andlaşmaları, görüşmeleri bitmeden bu sorunları 
aranızda çözemediğiniz takdirde, bunun mutlaka zorunlu yargıya gitmesi gerekir, yani Uluslararası Adalet Divanı'na gitmesi gerekir" demiştir.

Avrupa Birliği'nin Ege sorunlarına resmi belgeli olarak el atmasının ve bundan sonra bize hep "Ege sorununu çözün ve Kıbrıs'1 çözün" şeklindeki yaklaşımlarının başlangıcı böyle bir belgeyle ortaya çıkmıştır.

Daha sonra 20 Kasım 1997'de Avrupa Birliği devlet başkanları ve başbakanlarının toplandığı Lüksembourg Zirvesi'nde Yunanistan, Türkiye'nin adaylığına açıkça karşı çıkmıştır. Avrupa Birliği, artık tam üyesi olan Yunanistan'ın bu şantajını kabul etmiş ve 1997'de Lüksembourg Zirvesi'nde Türkiye'yi aday ülkeler arasına dahil etmemiştir.

Ancak Lüksembourg Zirvesi'den sonra gelişmeler başka türlü olmuştur ve 1999'da barışçı çözüm yolları arayışında bir yön değişikliği olmuştur. Bunda ilk etkili olan unsur 15 Şubat 1999 tarihinde Kenya'da Öcalan'ın yakalanıp Türkiye'ye getirilmesi olayıdır. Abdullah Öcalan Kenya'da yakalandığında, Yunan Büyükelçiliği'nde saklandığı, Yunanistan Dışişleri ve İstihbaratı tarafından oraya götürüldüğü ve muhafaza edildiği çok açık bir şekilde ortaya çıkmıştır.

Bunlar ortaya çıkınca Yunanistan bakımından bir suçluluk duygusu söz konusu olmuştur. Bunun üstüne belki Türkiye çok daha fazla giderdi, ama çok fazla gitme yolunu tercih etmemiştir. Biraz gidilmiştir, ama Türkiye bunu bir başka girişimle yararlanılır hale getirmeye çalı̧̧ıştır. Şöyle yapılmıştır: Mayıs 1999'da Türkiye Yunanistan'a bir mektup göndererek; "İkili sorunları çözme yolları arayalım ve bu arada terörizme karşı ortak mücadele edelim, artık böyle kendi başına bize karşı oyuna girme" mesajını da vermiştir. Yunanistan, bir yandan Kıbrıs konusuna öncelik verdiği ve Ege sorunlarını bir süre kenara bırakabilmeyi tercih ettiği için, diğer yandan bu suçluluk duygusu içinde olduğundan dolayı bunu açıkça ret edememiş ve Haziran 1999'da mektubunda: "Ortak çıkar bulunan alanlarda işbirliği için diyalog yapalım” şeklinde cevap vermiştir. Haziran 1999'da, yani Yunanistan'ın cevabından hemen sonra iki dışişleri bakanı New York'ta buluşmuş ve ortak çıkarlar bulunan alanlarda altı tane komitenin çalışmasını öngörmüşlerdir. Bu ortak çıkar alanları da şu şekilde saptanmıştır: Turizm, çevre, kültür, suçlarla mücadele, terörizm, kaçak göç, her şey dahil ticaret ve bölgesel işbirliği. Temmuz 1999'da da bu komiteler çalışmaya başlamıştır. Bu arada Ağustos 1999'da hem Türkiye'de hem de Yunanistan'da deprem olgusunu hatırlıyorsunuz. Aşağı-yukarı bunu hepimiz biraz daha canlı hatırlıyoruz. İşte onların bize yardıma gelmesi, bizim hemen gitmemiz, ilk gidenlerden olmamız kamuoyunda da bu barışçı çözüm yolları arayışının desteklenmesi şeklinde bir sonuç doğurmaya başlamıştır.

Şimdi bütün bunlardan sonra Yunanistan 1999 içinde, 10-11 Aralık 1999'da Avrupa Birliği'nin Helsinki Zirvesi'nde artık 1997'deki Lüksembourg Zirvesi'nde benimsediği yaklaşımından vazgeçmiş ve 
Türkiye'nin önüne, aday üye olarak Avrupa Birliği çerçevesinde kabul edilmesi konusunda engel koymama yoluna gitmiştir. Ama bunda, iki şey etkili olmuştur. Birincisi; diğer devletlerin "Bazen sınırı aşıyorsun" mesajıdır. İkincisi ise Kıbrıs'a öncelik vermiş olmasıdır. Yunanistan, Kıbrıs sorununu hep Ege sorunlarından önce çözülmesi gereken sorun olarak göstermiştir. KKTC'yi, Kıbrıs Türklerini hep kenara atmış; "Benim muhatabım olsa olsa -Rum yönetimi için de bu böyle- Türkiye Cumhuriyeti'dir" şeklinde bir yaklaşımı olduğundan 1999'da Kıbrıs'ın tek başına, gerekirse Rum yönetimiyle girebilmesini sağlamak üzere, böyle bir yaklaşımı benimsemiştir. Böylece Ege sorunlarını biraz uykuya alır bir yaklaşım içinde konuya yaklaşmıştır. Ama 1999 Helsinki Zirvesi konusunda da Kıbrıs'tan başka, Ege sorunlarına ilişkin de bir koşul vardır. Ege ile ilgili olarak kabul edilen özünde şudur: Sınır uyuşmazlıkları ve bunlara ilişkin öteki sorunlar. Yani ne gibi sorunlar olabilir? Belki işte Sayın Kurumahmutoğlu'nun sözünü ettiği adaların aidiyeti, sınır uyuşmazlığına bağlı sorunlardır. Onu belirleyeceksiniz ki sınırı belirleyebilesiniz, aidiyeti belirleyeceksiniz. Böyle de bir kelime vardır. Bunu bir gün yetkililerimizin bu kelimeyi de unutmaması için bilgilerinize sunuyorum.

$\mathrm{Bu}$ çerçevede: "İki taraf işin çözümü konusunda her türlü çabayı göstermelidir.Bu sınır konuları makul bir sürede bu iş çözülemezse, o zaman işin Uluslararası Adalet Divanı'na götürülmesi gerekmektedir ve 2004 yılı sonundaki Zirvede bu durum tekrar gözden geçirilecektir, değerlendirecektir" denilmiştir.

Bunun üzerine Türk Hükümetinde şöyle bir tereddüt olmuştur; "Acaba bize bunları Avrupa Birliği'ne üyeliğimiz konusunda bir ön koşul olarak mı söylüyorlar?"

Buna Hükümetimiz, o zaman Ecevit Hükümeti; "Böyle ön koşulları bize koymamanız gerekir. Avrupa Birliği müktesebatının gereklilikleri içinde bunun yer almaması gerekir" diye itiraz etmiştir. O zaman işte Solano ve Verheugen ikna etmek için Türkiye'ye gelmişler ve dönem başkanı Finlandiya Başbakanı Liponen'in bir mektubunu Ecevit'e sunmuşlardır. O mektupta özde şunu demişlerdir:

"Bunlar ön koşul değildir. Bunlar sadece siyasi görüşmeler bakımından öngördüğümüz verilerdir. Sizin üyeliğinizin ön koşulu, hukuksal bir ön koşul şeklinde değildir" demişlerdir.

İkincisi 2004 yılı ile ilgili cümledir. Bu cümle "2004 yılı sonu tekrar değerlendireceğiz" anlamındadır. "Yoksa 2004 yılının sonuna kadar Uluslararası Adalet Divanı'na Ege sorunlarını götürün demiyoruz” şeklinde ifadeye yer vermişlerdir.

Bu çerçevede Türkiye ile Yunanistan arasında, Türkiye'nin aday üye olması da kabul edildikten sonra belirli bir yumuşama ortamı içinde, daha önce sözünü ettiğim komitelerin de çalışması sonucunda sözü edilen 
alanlarda 10-15 civarı andlaşma imzalanması yoluna gidilmiştir. Turizm, deniz taşımacılığı, gümrük yönetimleri işbirliği, bilim ve teknoloji, çevre, yatırımlar, suçlarla mücadele, kültür ve tarımsal işbirliği konuları da başlıcaları olmak üzere bir takım andlaşmalar imzalanmıştır.

Ve bunlara ek olarak, paralel bir şekilde de iki devletin makamları arasında 2000 yılından bu yana "Güven arttırıcı önlemler" denilen önlemler konusunda da anlaşılmıştır. Bunlardan bir tanesi dışişleri bakanları ve milli savunma bakanları arasında direkt telefon bağlantısının kurulmasıdır İkincisi ise Genelkurmay Başkanlıkları arası üst düzey görüşmelerin yapılmasıdır. Bununla Genelkurmay Başkanı dâhil, gerektiğinde askerlerin tatbikatlara çağrılması, birinin yaptı̆̆ Türkiye'ye geldiğinde geçen ay "it dalaşı" söz konusu olduğunda telefonla bunu önleme girişimi şeklinde birtakım güven arttırıcı önlemlerin bulunması yoluna girilmiştir.

Bu arada bütün bu komite çalışmalarına paralel olarak 2001 Mart'ında “araştırmacı görüşmeler” Exploratary" diyeceğimiz -istikşafi görüşmeler adı da kullanılıyor- görüşmeler yapılması kararlaştırılmıştır.

Görüşmeler konusunda dışişleri bakanları, müsteşarları veyahut da siyasi direktörleri -müsteşar yardımcılarıdır onlar- arasında görüşmeler yapılması kabul edilmiştir. Bunlar 27-28 civarı bu güne kadar yapılmıştır. $\mathrm{Ne}$ gibi sonuçlar elde edildiğini bilemiyoruz. Ama bütün bunlar sonucunda bilinen bir şey var ki, pozisyonlar değişmiş değildir. Arama süreci kesilmemiştir. Her devlet daha önce az-çok iki tarafın da tezini ifade ettiğimiz görüşlerini ifade etmeye devam etmektedir ve bir yol, yöntem de henüz bu çerçevede çıkmış değildir.

Şimdi en son olarak 17 Aralık 2004 Avrupa Birliği Brüksel Zirvesi'nde bu sınır uyuşmazlıkları denilen konuda, yani Ege sorunları itibarıyla yine barışçı çözüm yolunun vazgeçilmez olduğu vurgulanmış, uyuşmazlıklar için araştırmacı görüşmelerin yapılmasından memnuniyet duyulduğu ifade edilmiştir. Ama gerektiğinde uyuşmazlıkların Uluslararası Adalet Divanı'na götürülmesi ifadesi de kullanılmıştır ve "Avrupa Birliği durumu izleyecek ve değerlendirecektir" denilmiştir. Yani Avrupa Birliği; "Uyuşmazlığı çözün, öyle gelin!" demekten vazgeçmiş değil, ama Yunanistan Ege sorunları itibarıyla baskıcı bir yaklaşımda da -şu ana kadar- bulunmamıştır. Çünkü Kıbrıs sorununun çözümünü, Türkiye'nin Güney Kıbrıs Rum Yönetimi'nin altındaki Kıbrıs Cumhuriyeti Devleti'ni tanımasını sağlamaya çalışmaktadır. Uyum protokolü vesaire hep bu amaçlara yönelik bir takım etapları, aşamaları oluşturur nitelikteki verilerdir.

Bir gün Ege sorunları tabii ki su yüzüne çıkacaktır. Avrupa Birliği çerçevesinde Yunanistan'dan başka, onların da, "tam üye olmak istiyorsanız bu konuları çözmeniz gerekir" şeklinde bir baskısı halen vardır. Ama bu siyasal düzeyde öyle dayanılmaz bir baskı değildir. Bu önümüze bir ön koşul 
olarak zaman içinde çıkarılacaktır diye beklemek gerekir. Hangi aşamada, ne zaman çıkacak? Onun hesabını yapmak lazım ve dolayısıyla Ege sorunları, Kıbrıs, Türkiye'deki azınlıklar konuları, Ermeni sorunu vesaire gibi başka sorunlarla birlikte Avrupa Birliği üyeliği konusunu değerlendirirken Türkiye'nin o ucu açık görüşmeler çerçevesinde yapılacak görüşmeleri nasıl değerlendirmesi konusunda çok dikkatli olması gerekir. Sadece bir "görüşme başladı" dedirttirmek için Türkiye'nin ulusal çıkarlarını ilgilendiren konularda ödün vermememiz ve buna çok dikkat etmemiz gerekmektedir. Bunun formülünü öncelikle Hükümet, Dışişleri Bakanlığı ve ilgili diğer kurumlarımız bulacaklardır. Ama bugün gündemde görünmeyen Ege sorunları aslında çok gündemdedir. Sayın Başkanımızın dediği gibi, başımızın daha sonra ağrımaması için bu konularda sürekli dikkatli çalışmalar yapılmasından hiç vazgeçmemiz gerekiyor.

Çok teşekkür ederim dinlediğiniz için.

PROF. DR. YAVUZ ERCAN (OTURUM BAŞKANI): Ben de size teşekkür ediyorum. Düşünülen süreyi çok geçmiş olduğumuz için soru-cevap kısmını mümkün olduğu kadar kısa tutacağım. 15 dakikayı geçmemek üzere ve sadece soru sormak isteyenlere söz hakkı vereceğim. Yalnız soru soranlardan sorularını hangi konuşmacıya sorduklarını belirtilmelerini rica ediyorum.

Evet, sorusu olan var mi? Buyurun.

MUZAFFER BUMİ: Efendim ben soruyu hangi konuşmaciya soracağımı pek bilmiyorum ama en uygun hangisi olursa o cevaplasın diyorum. Efendim son zamanlarda Türkiye ile Yunanistan arasındaki parlamentolar arası ilişkiyi geliştirmek üzere Meclis Başkanımızın bu casus belli olayı ile ilgili bir açıklaması oldu. Yani "Bunu biz kaldıralım, ilişkilerimiz gelişsin” babında bir şeydi. Bu konudaki sayın sunucuların görüşlerini alabilir miyiz? Bunun etkileri hususunda, müspet, menfi...

PROF. DR. YAVUZ ERCAN (OTURUM BAŞKANI): Sayın Başeren, siz cevap verir misiniz?

PROF. DR. SERTAÇ BAŞEREN: Teşekkür ederim. Casus belli'yi kaldırırsak ne olacak? Bunu haritada gösterdik. Karasuları 12 mile çıkartıldığı takdirde bu Ege'de Türkiye için dayanılmaz durumdur. Casus belli bunu durdurmaktadır. Casus belli hukuka uygun mudur, değil midir? Bunun tartışmasını bir yana bırakın, ama bu feci tabloyu önlemenin başka yolu yoktur. Bunu görmek gerekir.

Öbür taraftan Casus belli'nin hukukiliği meselesi de, tartışılır ve konuşulur. Yunanistan Uluslararası Adalet Divanı'nın ülkesel mevzulara ilişkin olduğunu söylediği kıta sahanlı̆̆ını Türkiye'nin elinden almak istemektedir. Bu bağlamda bile değerlendirebilir. Şu söylenebilirdi: “Türkiye, eğer Yunanistan karasuları 12 mile çıkartırsa meşru müdafaa 
durumunda kalabilir" denilebilirdi. Bu belki daha yumuşak, daha kabule dilebilir bir söyleyişti.

Bu bağlamda şunu da söyleyeyim: Bu karasuları meselesi o kadar önemlidir ki, -Hocam anlattı- bu işler nasıl bir çözüm usulüne bağlanmıştır. Bana sorarsanız karasuları meselesi çözülmeden Türkiye Uluslararası Adalet Divanı'na filan da gidemez. Bunun şu sebeple söylüyorum: Karasuları mevzuna bağlı olarak Casus belli'yi koyduk ama bu sadece karasuları meselesi değildir. Kıta sahanlığı bakımından da önem taşımaktadır. 12 mil haritasını şimdi arkadaşım göstersin. Karasuları 12 mile çıktıktan sonra hangi kıta sahanlığını kazanacak Türkiye? Bana söyler misiniz? Bir bakın şu haritaya... Bir 12 mil haritası, bir tane bulalım, üzerinden konuşalım. Dehșet verici bir durum var.

Sonra bir başka konu daha var. Ona da değinmek istiyorum. Bakın, şu 12 mil haritasını görün. Biz Casus belli ilan etmeseydik Yunanistan işte bunu yapacaktı. (Egemenliği andlaşmalarla Yunanistan'a devredilmemiş ada, adacık ve kayalıklarla bunların karasularını kast ederek) Pembeler de ona ait olacaktı. Ortaya çıkacak tablo bu olacaktı. Bu tablo ortaya çıktıktan sonra hangi kıta sahanlığı mevzunu Türkiye kazanabilir? Bana söyleyebilir misiniz? Casus belli sadece Türkiye'nin karasuları ile ilgili haklarını değil, kıta sahanlığı alanlarını da koruma altına almaktadır. Kaldı ki, söylediğim gibi, Yunanistan karasularını 6 milin üzerine çıkartarak Türkiye'nin egemen haklarını elinden almaktadır. Bence bu mevzu öyle bir jest uğruna filan ortadan kaldırılacak bir konu değildir.

Müsaade ederseniz bir konuya daha değinmek istiyorum. Pazarcı Hocam çok haklı olarak hep Kıbrıs mevzunun ön plana çıkartıldığını söyledi. Doğrudur, öyle de olmuştur ve altını çizerek dedi ki: Kıbrıs Rum Kesimini, (GKRY'yi) Türkiye'ye Kıbrıs olarak tanıtmaya çalışıyorlar. Eğer bu gerçekleşirse Ege savunulabilir olmaktan çıkacaktır. Evet, eğer Kıbrıs'ı biz, GKRY'yi Kıbrıs olarak tanırsak, Ege savunulabilir olmaktan çıkacaktır. Kıbrıs'ın gölgesinde neleri kaybediyoruz? Aslında bugün onu anlattık. Biz Kıbrıs'1, GKRY'yi Kıbrıs olarak tanıyacaksak bunu Avrupa Birliği'ne girmek için yapmayacak mıyız? Görüşmeleri başlatmak ya da sürdürmek için yapıyor olacağız,. Arkasından Kardak Kayalıkları için direnirseniz görüşmeyi kesmiş olmayacak mısınız? O zaman adama sorarlar, yani; "Sen deli misin kardeşim?" derler, "Koskoca adayı verdin, arkasından Kardak için görüşmeleri kesiyorsun”. Bu Yunanistan adına doğru bir strateji, Türkiye için katlanılmaz bir durum.

Teşekkür ederim.

PROF. DR. YAVUZ ERCAN (OTURUM BAŞKANI): Ben de teşekkür ederim. Evet, buyurun.

BURHAN DURDU: Benim sorum Ali Bey'e olacak efendim. Basından öğrendiğim kadarıyla Yunanistan bugün toprak sınırlarının sekizde birini 
harp sahalarında kazanmış. Sekizde yedisini ise masa başında kazanmıştır. Ülke olarak bugün gerek Ali Bey, gerekse Hocam Sertaç Bey 12 mili detaylı şekilde anlattı. Hakikaten de bugün vicdani olarak etlerim diken diken oluyor. Eğer Yunanistan toprak sınırları, karasularını 12 mile çıkarırsa, vatandaşın gözünün içine kadar girmiş olacaktır. Ben ülke olarak Hocamdan şunu istiyorum: Nerede hata yaptık? Bu hususta ülke olarak neler yapmamız lazım?

Teşekkür ederim efendim.

ALİ KURUMAHMUT: Ben teşekkür ediyorum.

Türkiye büyük bir devlet ve çok geniş imkân ve kabiliyetlere sahiptir. Üç tarafı denizlerle çevrilidir. Bütün denizlerde çözüm bekleyen çok sorun bulunmaktadır. Türk boğazları bölgesi bizim egemenliğimizdedir ama çok karmaşık bir bölgedir.

Ancak Türkiye'nin bu sorunlarına çözüm üretebilecek tabibi yok. Türkiye'nin uluslararası hukuk alanında doktora ve üst düzeyde eğitim almış insan sayısı 20 civarındadır. Onlar içerisinde Deniz Hukuku'na yönelmiş olanlar, işte iki-üçü burada, iki-üç tane de dışarıda var. Yine bunlar içerisinde özel olarak Türkiye'yi çevreleyen sorunlar konusunda uzmanlaşmış insanı yoktur. Kısa ve orta vadede, şahsen ben bir çözüm beklemiyorum. Kisa ve orta vadede bu taarruzi stratejiye dur diyebilirsek bizim için kâr olur kanaatindeyim.

İkincisi; az önce Hocam ifade ettiler, buna çok somut bir örnektir Casus belli. Casus belli'yi ikiye ayırmak lazımdır. Birincisi; 1976'dan itibaren tez üretemeyen, cevap veremeyen Türk tarafının şartlı bir zihniyetle "Casus belli" demesidir, "Gelirsen öldürürüm! Gelirsen vururum! Gelirsen kırarım!" demesidir. Ama 8 Haziran 1995 yılında Türkiye Büyük Millet Meclisi'nin aldığı karar böyle bir karar değildir. Bu hukuki bir karardır. Kuvvet kullanma konusunda yazan-çizen iki hocam da burada; o karar somut olarak okunduğu zaman orada Casus belli demez. Orada Yunanistan'ın 1 Haziran 1995 yılında yaptı̆̆ı açıklamaya yer vererek, Türkiye'nin Ege'deki hakları ve temel ulusal çıkarlarının çok büyük zarar göreceğini ifade eder ve bu durum Türkiye'yi hakkını korumak zorunda bırakır. Kuvvet kullanma da dâhil hükümete yetki devreder.

Yani burada özellikle Casus belli anlayışı ve yaklaşımı Türkiye'nin bu konulardaki çaresizliğini gösteren bir durumdur. Bu durum bugün de vardır, ama Türkiye Büyük Millet Meclisi'nin 08 Haziran 1995'de almış olduğu kararı bunun dışında bırakmak gerekir.

Biz bu konularda yazan-çizen üç-beş insanız. Hakikati haykırıyoruz, ama duyuramıyoruz. Oysa Yunanlılar bunu çok daha iyi duyuyor. 
Yani söyleyecek çok şey var, ama kısa ve orta vadede çözüm göremiyorum. Bugün Yunanistan batı Avrupa'ya ve Amerika'ya her sene 200 doktora öğrencisi gönderir. Yunanlılar "Bunların 10 tanesi geri dönse benim için yeterlidir" diyorlar. Biz ise bu konunun üzerinde çalışan adam bulamiyoruz.

PROF. DR. YAVUZ ERCAN (OTURUM BAŞKANI): Evet, son bir soru olarak... Buyurun...

BAHADIR SELIM DILLEK (TERCÜMAN GAZETESİ DİPLOMASİ MUHABİRİ): Efendim, biraz önce istikşafi görüşmelerden bahsettiniz Sayın Pazarcı. İstikşafi görüşmelerin içeriği açıklanmadı, açıklanırsa da bu sürecin çökeceği söyleniyor. Ama Ege konusunda devletin bazı gizli belgeleri ve bilgileri dişında çok bilinmeyen şeyler yok. Dolayısıyla üç aşağı-beş yukarı istikşafi görüşmelerin de çerçevesi bellidir. Peki, siz nasıl bir sonuç bekliyorsunuz? Yani istikşafi görüşmelerden; "Biz Ege sorununda şunları, şunları sorun olarak kabul ettik" gibi mi bir yaklaşım ya da "Ege'de sorun şudur, çözüm yöntemi şudur, şuraya gidilsin" gibi üçlü bir paket mi düşünüyorsunuz? Nasıl bir şey çıkacak buradan? Veya çıkacak mı? Önemli olan soru bu, çünkü 17 Aralık kararında Ege sorunlarına atıf yapılmadı. Bunun gerekçesi olarak da bir şekilde istikşafi görüşmelerin yürütüldüğü gösterildi. Şimdi bu süre uzadıkça gelişmeler Türkiye'nin lehine mi olacak, yoksa aleyhine mi?

Teşekkür ederim.

PROF. DR. HÜSEYİN PAZARCI: Sorunuzun cevabı olarak, içerikle ilgili siz bazı tahminlerde bulundunuz ama, ben hakikaten bir somut veri olarak içerikle ile ilgili bir bilgi sahibi değilim. Sizin dediğiniz türden soruların belirlenmesi, artı yöntemlerin aranması şeklinde geçmesi gerekir. Onların öyle olabildiğini, olacağını tahmin ediyoruz. Ama onun içeriğinin ne yönde ve gerçekten çözüme ulaşacak ilk birtakım çözüm yolları üzerinde ilerlemeler var mi, ben bilmiyorum.

Ama benim tahminim, işin objektif verileri itibarıyla bakıldığında, bunun ikili düzeyde elde edilebilecek yol ve yöntem olduğudur. Aksi takdirde iş üçüncü kişilerin müdahalesi çerçevesinde, yani bugün Avrupa Birliği'nin müdahalesi çerçevesinde ve belki genel bir şekilde uyuşmazlıkların barışçı çözümü dünya, uluslararası güvenliği vesairesi şeklinde geçecektir.

Türkiye'nin Avrupa Birliği çerçevesinde, dolayısıyla belirli birtakım baskılar ile karşılaştırılmak durumunda bırakılmasıyla iş o tarafa çekilmeye çalışılacaktır. Bu görüşmelerle ilgili olarak zaten Avrupa Birliği, 17 Aralık 2004 kararında görüşmelerin bir kere paket paket yapılacağını -32 idi, 36 paketten söz edilir oldu- açıkladı. Herbir paketin açılış ve kapanışında 
birtakım ölçütlere bakılacağı ve sorunlar varsa, o zaman bunlar hesaba katılarak görüşmelerin askıya alınacağı veyahut da yavaşlatılacağı şeklinde bir mekanizma öngörülmüş durumdadır. O mekanizma içinde gerek Yunanistan, gerekse "Kıbrıs Rum Cumhuriyeti" bunu sonuna kadar kullanmaya çalışacaklardır. Dolayısıyla istikşafi görüşmelerin sonuç vermesi dahi Avrupa Birliği mekanizması çerçevesinde, aday üyeliğimiz ve katılma görüşmeleri konusu çerçevesindeki verilere bağlı olarak, hep değerlendirilecektir. Yunanistan hemen "Tamam, bu işi kabul ediyorum" şeklinde bir tavır takınmayacaktır.

PROF. DR. YAVUZ ERCAN (OTURUM BAŞKANI): Evet... Saygıdeğer konuklar, Görüldüğü üzere Ege sorunları, bir kez daha görüldüğü üzere Türkiye açısından olağanüstü bir stratejik önem taşıyor. İki ülke arasında bir barış denizi olması gereken Ege, Yunanistan'ın yayılmacı politikası yüzünden bir düşmanlık denizi haline gelmiştir. Geçmişte ve günümüzde Türkiye konuyla ilgili yanlışlar yapmış olabilir. Bu Yunanistan'ın önerilerinin ve oldu-bittilerinin haklı olduğunu göstermez. Türkiye düne kıyasla bugün Ege sorunları konusunda daha bilgili ve daha bilinçlidir. Dileriz Yunanistan da bu durumu görür ve Megali İdea politikasından vazgeçer. Her gününüzün bir öncekinden daha mutlu, daha umutlu, daha güzel, daha sağlıklı, daha başarılı geçmesi dileğiyle hepinize iyi akşamlar diliyorum. 


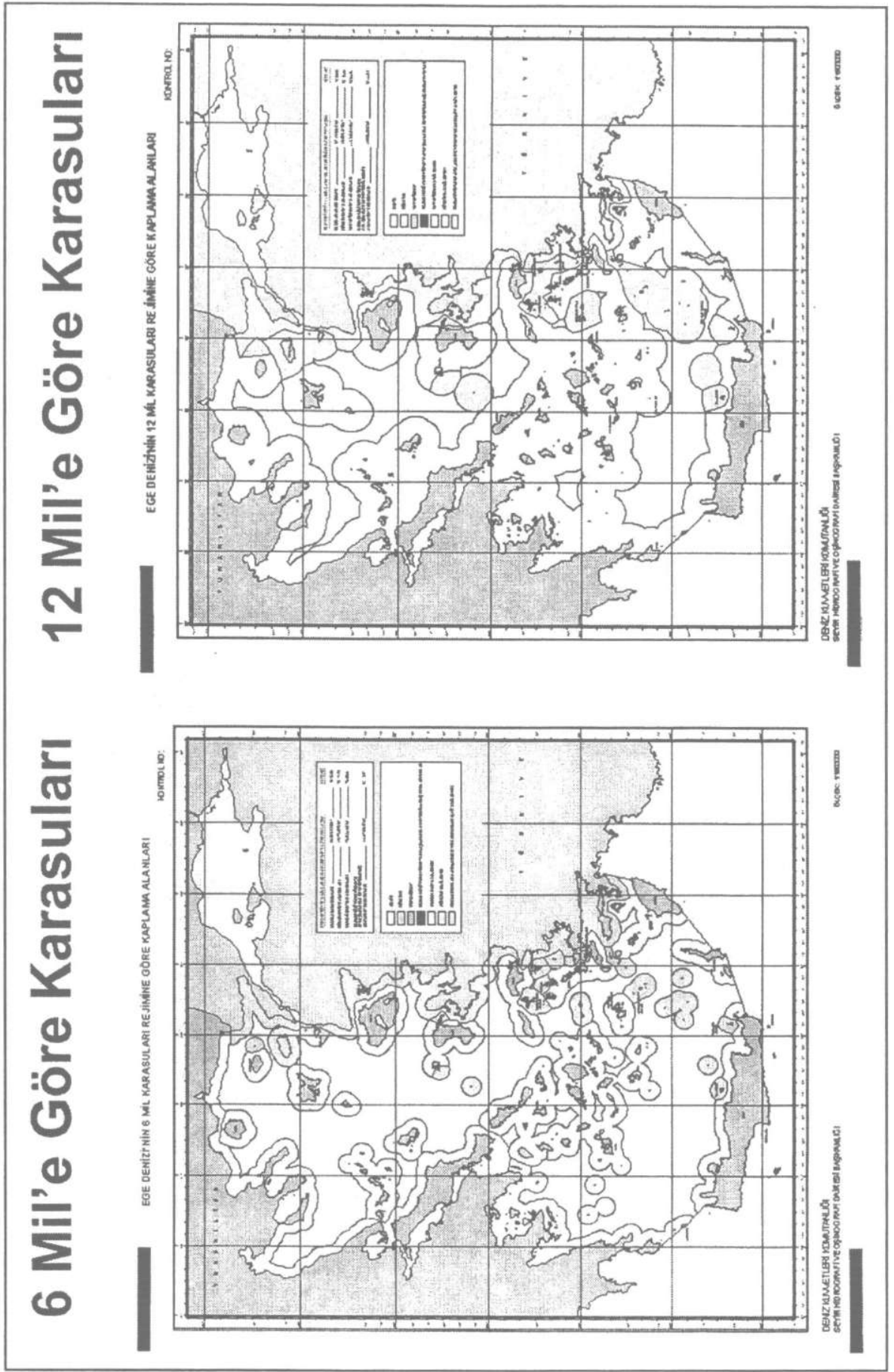

Harita 1 


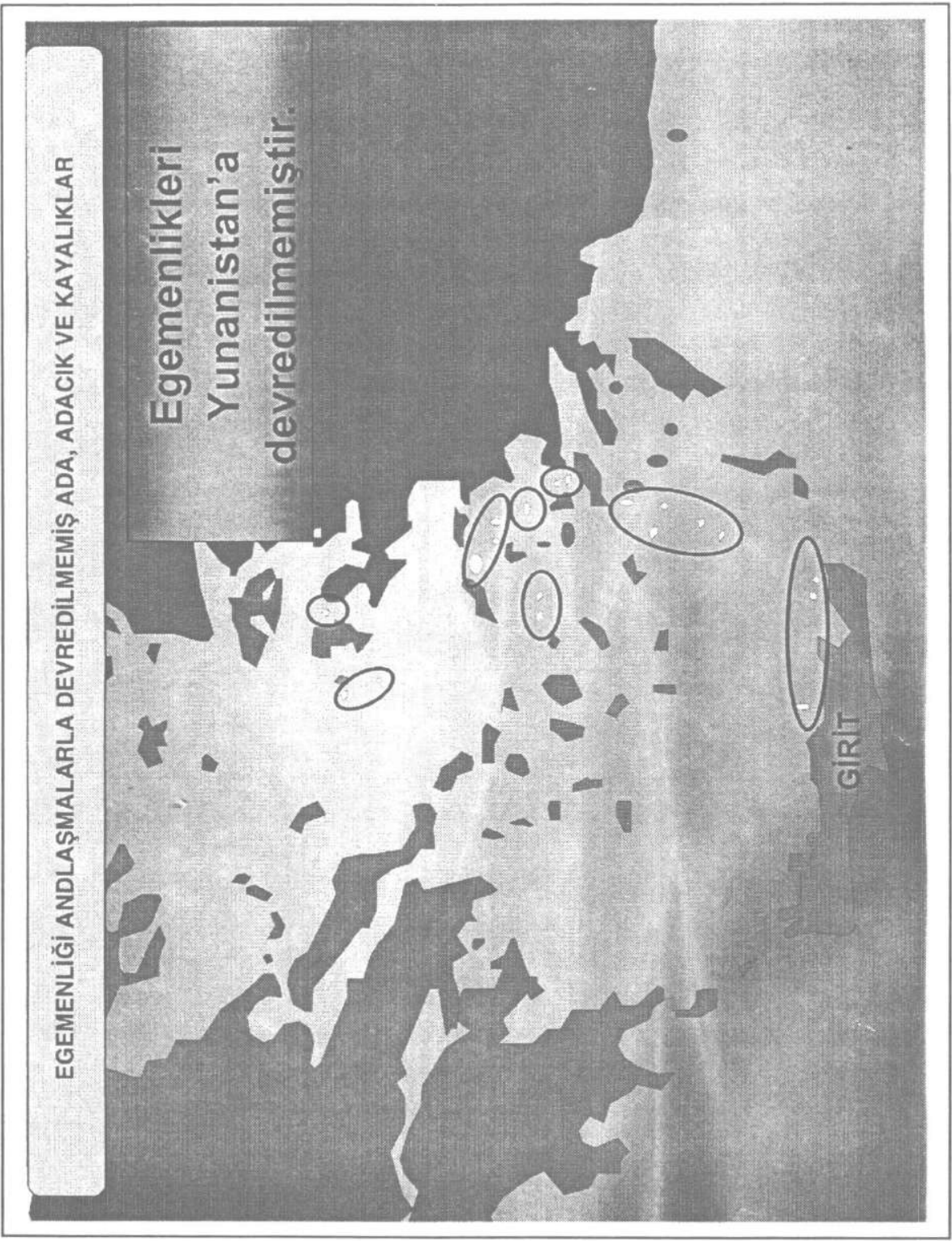

Harita 2 


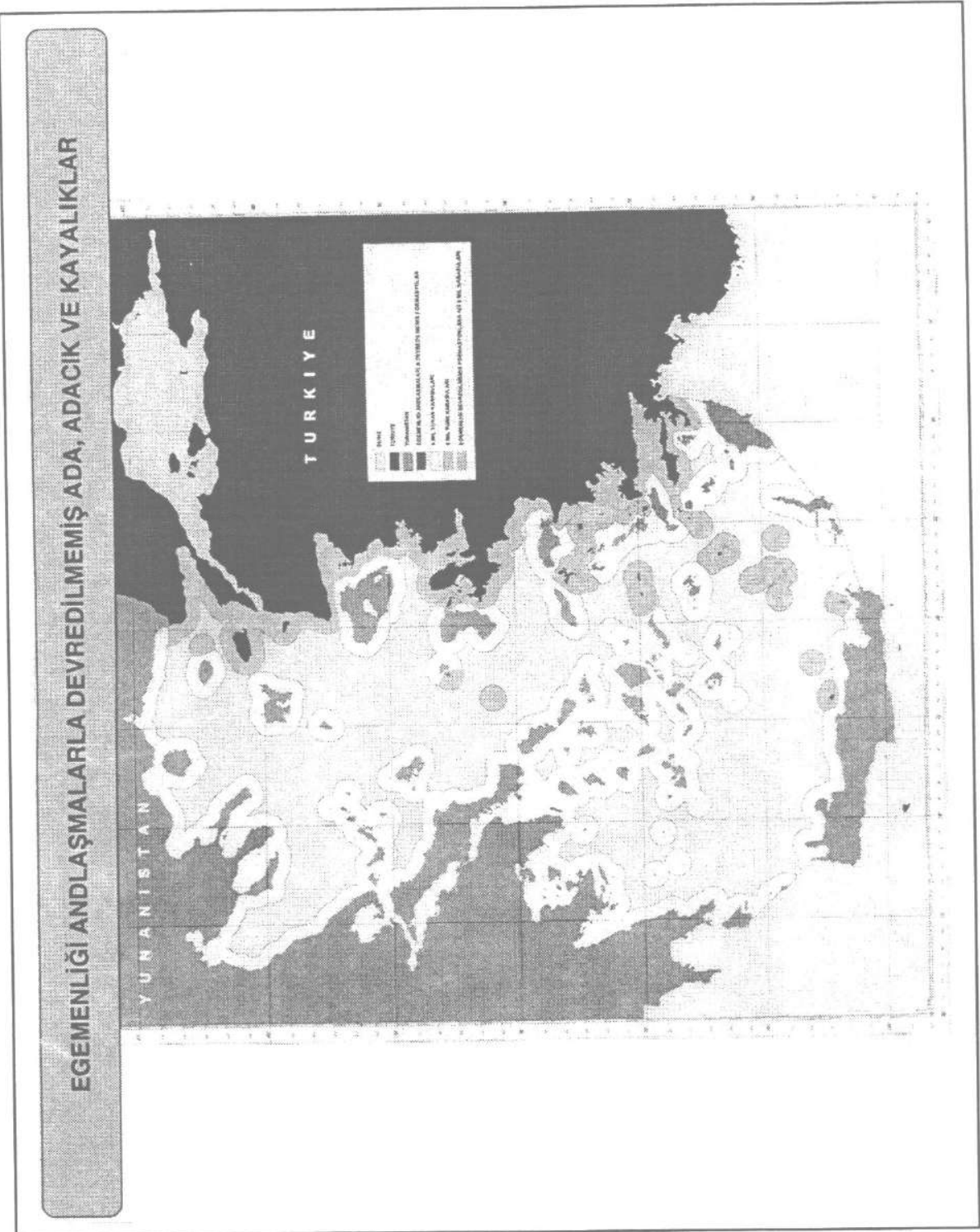

Harita 3 